\title{
NAKNADA TROŠKOVA U SLUČAJU POVLAČENJA TUŽBE I ODRICANJA OD TUŽBENOG ZAHTJEVA PREMA NOVELIRANOM ZAKONU O PARNIČNOM POSTUPKU
}

Prof. emer. dr. sc. Mihajlo Dika*

\author{
UDK: $347.922 .3(497.5)$ \\ https://doi.org/10.30925/zpfsr.41.1.1 \\ Ur.: 15. siječnja 2020. \\ Pr.: 19. veljače 2020. \\ Izvorni znanstveni rad
}

\begin{abstract}
Sažetak
Prije Novele Zakona o parničnom postupku iz 2019., tužitelj koji bi povukao tužbu bio je dužan protivnoj stranci naknaditi parnične troškove, osim ako bi tužba bila povučena odmah nakon što bi tuženik udovoljio zahtjevu tužitelja, u tom bi slučaju troškove postupka bio dužan tužitelju nadoknaditi tuženik. Novelom iz 2019. navedene su odredbe zamijenjene novim prema kojima je tužitelj koji povuče tužbu ili se odrekne tužbenog zahtjeva dužan tuženiku naknaditi troškove postupka, osim ako je tužitelj te radnje poduzeo nakon što je tuženik udovoljio njegovu zahtjevu ili zbog drugih razloga koji se mogu pripisati tuženiku, u kojem je slučaju troškove postupka dužan tužitelju naknaditi tuženik. $U$ radu se, u okviru sustavne $i$ cjelovite obrade instituta uređenog navedenim normama, nastoji odrediti značenje i domašaj novina koje su Novelom 2019. unesene $u$ taj institut. Pritom se posebno problematizira $i$ relevantnost niza stajališta zauzetih u sudskoj praksi i doktrini na temelju prije važećeg uređenja instituta s aspekta njegova novog normativnog određenja.
\end{abstract}

Ključne riječi: naknada troška; povlačenje tužbe; odricanje od tužbenog zahtjeva; Novela Zakona o parničnom postupku iz 2019.

\section{1. $U V O D$}

Zakon o parničnom postupku ${ }^{1}$ izmijenjen je i dopunjen Novelom iz 2019., ${ }^{2}$ između ostaloga, i u dijelu kojim je njime bila uređena naknada troškova postupka

* Dr. sc. Mihajlo Dika, professor emeritus, Pravni fakultet Sveučilišta u Zagrebu; mihajlo.dika@, pravo.hr.

1 Narodne novine, br. 53/91., 91/92., 112/99., 88/01., 117/03., 88/05., 2/07., 84/08., 96/08., 123/08., 57/11., 148/11. - pročišćeni tekst, 25/13., 89/14. - Odluka Ustavnog suda Republike Hrvatske, 70/19. Za označavanje normativnog uređenja prema Zakonu o parničnom postupku nakon Novele iz 2019. koristit će se kratice ZPP, ZPP 19, Zakon, dok će se za označavanje toga zakona prije te novele rabiti kratica ZPP 13.

2 Zakon o izmjenama i dopunama Zakona o parničnom postupku, Narodne novine, br. 70/19. Za označavanje ovog zakona koristit će se kratice Novela 19. i Novela. 
u slučaju povlačenja tužbe. Prije Novele, tužitelj koji bi povukao tužbu bio je dužan protivnoj stranci naknaditi parnične troškove (158/1.1.), ${ }^{3}$ osim ako bi tužba bila povučena odmah nakon što bi tuženik udovoljio zahtjevu tužitelja, u kojem je slučaju troškove postupaka bio dužan tužitelju nadoknaditi tuženik (158/1.2.). Novelom su te odredbe, koje su bile redigirane $u$ jednom stavku, zamijenjene izmijenjenim $i$ dopunjenim odredbama članka 158. stavka 1. i 2. ZPP 19, koje glase:

Tužitelj koji povuče tužbu ili se odrekne tužbenog zahtjeva dužan je tuženiku naknaditi troškove postupka.

Iznimno od stavka 1. ovoga članka, ako je tužitelj povukao tužbu ili se odrekao tužbenog zahtjeva odmah nakon što je tuženik udovoljio zahtjevu tužitelja ili zbog drugih razloga koji se mogu pripisati tuženiku, troškove postupka dužan je tužitelju naknaditi tuženik.

Ako se usporedbe prijašnje odredbe stavka 1. članka 158. ZPP 13 i nove odredbe stavaka 1. i 2. članka 158. ZPP 19, može se konstatirati da se one međusobno razlikuju. Ponajprije po tome što su se prije važeće odredbe izrijekom odnosile samo na povlačenje tužbe, dok je novim odredbama ono što je bilo propisano samo u vezi s povlačenjem tužbe izrijekom prošireno i na odricanje od tužbenog zahtjeva. Zatim, novim su stavkom 2. članka 158. ZPP značenje slučaja u kojima tužitelj iznimno stječe pravo tražiti da mu tuženik naknadi troškove postupka, pored onoga u kojemu je tužitelj povukao tužbu zato što je tuženik udovoljio njegovu zahtjevu, dobili i svi drugi u kojima je tužitelj povukao tužbu ili se odrekao tužbenog zahtjeva iz razloga koji se mogu pripisati tuženiku.

Nova odredba stavka 1. članka 158. ZPP 19, jednako kao i odredba prijašnje reč. 1. stavka 1. članka 158. ZPP 13 , izraz je općeg pravila da se parnični troškovi naknađuju po načelu presumiranog davanja povoda za parnicu (154/1.). ${ }^{4,5}$ Okolnost da je tužitelj povukao tužbu ili da se odrekao tužbenog zahtjeva ima, naime, značenje specifične presumptivne baze kojom se, primjenom odredbe stavka 1. članka 158.

3 U ovom radu odredbe pojedinih zakona označavat će se navođenjem broja članka, stavka odvojenog kosom crtom od broja članka, te točke ili rečenice u istom stavku, odvojene točkom od broja članka ili stavka. Brojevi više stavaka ili točaka istoga članka ili stavka međusobno bit će razdvojeni zarezom. Crtica između brojeva dvaju članaka ili stavaka koristit će se radi označavanja da se sve odredbe između tih brojeva odnose na tekst ispred njih. Za označavanje pojedinih propisa rabit će se njihove kratice koje će biti definirane u tekstu. Jedino će se odredbe ZPP-a u zagradama navoditi bez naznake kratice toga zakona. Za označavanje judikature koristit će se kratice sudova koji su donijeli odluku na koju se referira: VS - Vrhovni sud Republike Hrvatske; VTS: Visoki trgovački sud Republike Hrvatske; ŽS - županijski sud koji će biti dodatno individualiziran naznakom kratice registarske tablice automobile. Odgovarajuće će vrijediti i za kratice sudova iz federalnih jedinica bivše države. Pojedini časopisi i zbirke sudske prakse označavat će se kraticama koje se uobičajeno koriste ili su se rabile u domaćoj literaturi.

4 Prema odredbi članka 154. stavka 1. ZPP-a, stranka koja u cijelosti izgubi parnicu dužna je protivnoj stranci i njezinu umješaču naknaditi troškove izazvane vođenjem postupka, dok je umješač na strani stranke koja je izgubila parnicu dužan naknaditi troškove koje je uzrokovao svojim radnjama.

5 Nina Betteto, Pravdni postopek, Zakon s komentarjem, 2. knjiga. (Ljubljana: GV Založba, 2005.), 46, odredbe članka 158. slovenskog ZPP-a iz 1999., s novelama iz 2002. i 2004., kvalificira kao posebne slučajeve naknade troškova po načelu krivnje. 
ZPP-a, izvodi presumptivni zaključak da je on time dao povod za parnicu u kojoj je do toga došlo, da je dao povod za parnicu koja je nepovoljno okončana po njega, koju je izgubio, zbog čega treba tuženiku naknaditi troškove postupka. ${ }^{6}$

S druge strane, navedena iznimka od pravila iz stavka 1. članka 158. ZPP 19, utvrđena u odredbi stavka 2. članka 158. ZPP 19, temelji se, također, na pravnopolitičkom stajalištu da troškove treba naknaditi protivnoj stranci ona stranka koja je dala povod za vođenje parnice, povod koji je u slučajevima na koje se odnosi ta iznimka dao tuženik, zbog čega je i bio tužen. Pritom, za razliku od slučaja u kojemu je troškove dužan tuženiku naknaditi tužitelj koji je povukao tužbu ili se odrekao tužbenog zahtjeva zato što se predmnijeva da je dao povod za vođenje parnice u kojoj je do toga došlo (158/1.), u slučajevima na koje se odnosi iznimka o kojoj je riječ tužitelj koji je povukao tužbu ili se odrekao tužbenog zahtjeva i koji traži naknadu troškova od tuženika treba uvjeriti sud da je tuženik dao povod za vođenje parnice time što će dokazati da je tek nakon podnošenja tužbe „udovoljio“ njegovu zahtjevu, odnosno dokazati da je poduzeo navedene radnje zbog drugih razloga koji se mogu pripisati tuženiku. Takvim bi ,dokazom o protivnom“ tužitelj obarao predmnjevu da je on dao povod za parnicu u kojoj je povukao tužbu ili se odrekao tužbenog zahtjeva, povod za parnicu koja je u tom smislu za njega nepovoljno okončana (arg. ex 158/2.) (pravilo o naknadi troškova na temelju dokazanog davanja povoda za parnicu).

Posebno pravilo da je tužitelj koji povuče tužbu dužan protivnoj stranci naknaditi parnične troškove (158/1.) bilo je, s jedne strane, potrebno zato da bi se stavilo izvan dvojbe tko je kome u tim slučajevima u pravilu dužan naknaditi troškove postupka, osobito stoga što povlačenje tužbe ne dovodi do meritornog okončanja spora, zbog čega se smatra da povučena tužba nije ni podnesena i tužitelj je može ponovno podnijeti (193/9.). S druge strane, ono je bilo potrebno i da bi se istaknula razlika prema slučaju u kojemu je tuženik, ipak, iznimno od toga pravila, dužan tužitelju naknaditi troškove postupka (158/2.). Drugi navedeni argument vrijedio bi i ako bi se tužitelj odrekao tužbenog zahtjeva.

Novim odredbama stavaka 1. i 2. članka 158. ZPP 19 izrijekom je riješeno pitanje koja je od stranaka ovlaštena i uz koje pretpostavke tražiti naknadu troškova postupka ne samo u slučaju povlačenja tužbe, već i u slučaju odricanja od tužbenog zahtjeva. Time su otklonjene prije postojeće interpretativne nedoumice treba li i u slučaju odricanja od tužbenog zahtjeva, uz koje pretpostavke i kako primijeniti

6 Navedeno pravilo vrijedi i u korist umješača na strani tuženika. U tom je smislu suđeno da u slučaju povlačenja tužbe umješač na strani tuženika ima pravo na naknadu parničnih troškova pod istim uvjetima kao i tuženik (ŽS ZG: Gž-892/2010-2 - IO VSRH 2/2010-190). U toj je rješidbi drugostupanjski sud zauzeo stajalište da umješač ima pravo na nadoknadu troškova postupka nakon povlačenja tužbe u smislu odredbe članka 158. stavka 1. ZPP-a, iako u toj odredbi umješač nije izričito naznačen kao osoba koja na to ima pravo, već samo stranka, i to stoga što iz odredbe članka 154. stavka 1 . ZPP-a proizlazi da su stranka i njezin umješač izjednačeni u pogledu prava na nadoknadu troškova od protivne stranke. O tome da stranka i „njezin“ obični umješač ipak nisu u svemu izjednačeni u pogledu prava na nadoknadu troškova usp. Mihajlo Dika, „O troškovnom statusu umješača nakon Novele Zakona o parničnom postupku iz 2019.“, Zbornik radova s V. Međunarodnog savjetovanja - Aktualnosti građanskog procesnog prava - nacionalna i usporedna pravnoteorijska i praktična dostignuća (Split: Pravni fakultet, 2019.), $1 \mathrm{i}$ slj. 
odredbe o naknadi troškova u slučaju povlačenja tužbe. Tim je novim odredbama izrijekom, međutim, riješeno i pitanje slučajeva u kojima tužitelj, iznimno od pravila da je on dužan naknaditi troškove tuženiku, ima, ipak, pravo tražiti naknadu troškova od tuženika. To je učinjeno tako što je rečeno da će tužitelj imati to pravo ne samo kad povuče tužbu ili se odrekne tužbenog zahtjeva odmah nakon što je tuženik udovoljio njegovu zahtjevu, već i kad je to učinio iz drugih razloga koji se mogu pripisati tuženiku.

I prema novom uređenju instituta naknade troškova u slučaju povlačenja tužbe i odricanja od tužbenog zahtjeva, premda su njime otklonjeni neki od problema kojima je bilo opterećeno prije važeće uređenje, nisu prevladane sve interpretativne nedoumice koje su se nametale i prema prijašnjem uređenju. Neke dodatne takve nedoumice otvorilo je, međutim, i novo, izmijenjeno i dopunjeno uređenje instituta. U nastavku rada nastojat će se naznačiti navedeni problemi i nedoumice te pokušati predložiti rješenja za njihovo prevladavanje.

U ovom ogledu nastojat će se relativno cjelovito obraditi institut o kojemu je riječ. Pritom će se novo uređenje instituta najprije razmotriti s aspekta povlačenja tužbe, a tek će se nakon toga rezultati te analize pokušati primijeniti i na odricanje od tužbenog zahtjeva.

\section{OSNOVNO PRAVILO (158/1.)}

\subsection{Određenje značenja}

Supra ad 1. citirana odredba reč. 1. stavka 1. članka 158. ZPP 13, prema kojoj je tužitelj koji bi povukao tužbu bio dužan protivnoj stranci naknaditi parnične troškove, Novelom 19 zamijenjena je novom odredbom stavka 1. članka 158. ZPP 19 kojom je otklonjena potreba ,proširenog” tumačenja prije važeće odredbe reč. 1. stavka 1. članka 158. ZPP 13, u smislu da ju je trebalo analogno primjenjivati i u slučajevima u kojima bi se tužitelj odrekao tužbenog zahtjeva - novom je odredbom stavka 1. članka 158. ZPP 19 to izrijekom propisano. Novelom 19 su, međutim, značenje i domašaj odredbe reč. 1. stavka 1. članka 158. ZPP 13 izmijenjeni, zapravo ograničeni, i proširenjem kruga slučajeva u kojima tužitelj koji povuče tužbu ima iznimno pravo tražiti naknadu troškova postupka od tuženika. Dok je doslovno prema prije važećoj odredbi reč. 2. stavka 1. članka 158. ZPP 13 tužitelj to pravo imao samo ako bi tužbu povukao nakon što bi tuženik udovoljio njegovu zahtjevu, po novome on to pravo ima i u drugim slučajevima u kojima povuče tužbu ili se odrekne tužbenog zahtjeva zbog razloga koji se mogu pripisati tuženiku (158/2. ZPP 19).

Prije Novele 19 važeću odredbu reč. 1. stavka 1. članka 158. ZPP 13 bilo je, naime, u kontekstu odredaba članka 158. stavka 1. ZPP 13 moguće barem dvojako protumačiti.

Prvo, strogo, u smislu da je tužitelj koji bi povukao tužbu, neovisno o tome zašto je to učinio i je li njegov zahtjev inače bio osnovan (osim ako je povlačenje tužbe uslijedilo odmah nakon što bi bilo udovoljeno njegovu zahtjevu), bio dužan tuženiku naknaditi parnične troškove. Od toga pravila nije smjelo biti iznimaka, osim 
navedenog, i svaki se tužitelj u parnici izvrgavao tom riziku. ${ }^{7,8}$ Takvo je tumačenje polazilo od shvaćanja da je jedinu u Zakonu izrijekom predviđenu iznimku od toga pravila, onu iz reč. 2. stavka 1. članka 158. ZPP 13, trebalo usko i doslovno tumačiti. Polazilo se od shvaćanja da je tužitelj koji je povukao tužbu dao, uz navedenu iznimku, povod za parnicu i da je zbog toga bio dužan protivnoj stranci naknaditi troškove postupka. Ta je implicirana predmnijeva o davanju povoda za parnicu, prema tom tumačenju, bila (relativno) neoboriva - tužitelj, osim u slučaju na koji se odnosila jedna jedina iznimka, nije smio moći dokazivati da je njegova tužba, sve dok nije nastao razlog zbog kojega ju je povukao, bila dopuštena i osnovana, pa ma kako razlog za povlačenje bio uvjetovan okolnostima koje su naknadno nastupile i koje su se mogle pripisati tuženiku. Po tom tumačenju tužitelj koji bi povukao tužbu iz drugih razloga, dakle ne zbog toga što je tuženik udovoljio njegovu zahtjevu, npr. jer je tuženik skrivljeno uništio stvar čiju je predaju utužio ili zato što je ona uništena slučajem koji se tuženiku dogodio, i koji ne bi imao interesa preinačiti tužbu i tražiti osudu tuženika za naknadu štete jer bi ovaj, npr. bio pred stečajem, „blokiran“, bez imovine itd., zbog čega bi daljnjim vođenjem parnice samo rasipao vlastita sredstva (i vrijeme), nije mogao tražiti naknadu troškova od tuženika. Naknadu tih troškova on, svakako, nije smio moći tražiti ni ako je do propasti utužene stvari došlo zbog slučaja za koji tuženik nije odgovarao, tada bi on bio dužan tuženiku naknaditi troškove postupka.

Po drugom tumačenju, pravilo da je tužitelj koji povuče tužbu dužan protivnoj stranci naknaditi troškove postupka, trebalo je shvatiti u smislu da je troškove postupka tužitelj bio dužan naknaditi tuženiku samo ako se razlog zbog koga je došlo do povlačenja tužbe ne bi mogao pripisati tuženiku, ako se ne bi dokazalo da je tuženik dao povod za parnicu. To je tumačenje svoje uporište moglo naći u elastičnijem određenju značenja izrijekom predviđene iznimke od osnovnoga pravila (158/1.2. ZPP 13, v. amplius infra ad 3.). Ono se djelomično moglo opravdati i odgovarajućim tumačenjem pravila o odgovornosti za naknadu troškova po načelu krivnje i objektivne uzročnosti (156.), ${ }^{9}$ koje je, uostalom, došlo (posredno) do izražaja i u odredbi članka 157. ZPP-a. ${ }^{10}$ Riječ je o tumačenju kojim bi se generalizirala

7 OS DU: GŽ-911/85 - PSP 31/89. U tom smislu i Branko Bazala, ,Naknada razmjernog dijela parničnih troškova“, Odvjetnik br. 1 (1958.): 34 te Borivoje Poznić, Komentar Zakona o parničnom postupku, (Beograd: Pravni fakultet, 2009.), 342.

8 Betteto, Pravdni postopek, Zakon s komentarjem, 46, ističe, pozivajući se na slovensku sudsku praksu, da je razlog zbog kojega se tužitelj odlučio povući tužbu bez važnosti. U tom se smislu navodi judikat prema kojemu nije bila relevantna kao razlog zbog kojega su tužiteljevi nasljednici povukli tužbu za novčanu naknadu neimovinske štete ni oštećenikova smrt. Sud je smatrao da je za odlučivanje o troškovima bitno to da do povlačenja nije došlo zbog ispunjenja zahtjeva.

9 Prema odredbi članka 156. stavka 1. ZPP, stranka je dužna neovisno o ishodu parnice nadoknaditi protivnoj stranci troškove koje je uzrokovala svojom krivnjom ili slučajem koji se njoj dogodio.

10 Članak 157. ZPP-a glasi: „Ako tuženik nije dao povod za tužbu i ako je prije nego što se upustio u raspravljanje o glavnoj stvari, priznao tužbeni zahtjev, tužitelj će nadoknaditi tuženiku parnične troškove.“ Ova odredba zapravo polazi od načela dokazanog nedavanja povoda za parnicu, načela po kojemu je stranka protiv koje je govorila predmnijeva da je dužna protivniku naknaditi troškove postupka zato što je izgubila spor (154/1.), da bi ostvarila pravo 
primjena načela dokazanog davanja povoda za izgubljenu parnicu koje bi imalo prednost u primjeni pred načelom presumiranoga davanja povoda u slučaju gubitka parnice. Po tom drugom tumačenju tužitelj nije trebao biti ni prema prije važećem uređenju dužan tuženiku naknaditi troškove postupka ako bi tužbu povukao nakon što bi tuženik uništio stvar čiju je predaju zahtijevao, svakako ako bi je imao pravo tražiti. Štoviše, u tom je slučaju on trebao imati pravo tražiti naknadu troškova od tuženika ako bi dokazao da je imao pravo tražiti stvar u momentu podnošenja tužbe, a da je ona uništena iz razloga koji se mogu pripisati tuženiku. U tom bi slučaju, naime, tuženik dao povod za parnicu u kojoj je naknadno, zbog razloga koji mu se mogu pripisati, zbog razloga za koje je on odgovoran, tužiteljev zahtjev postao neosnovan. Ovo se drugo tumačenje činilo pravičnijim i trebalo je poslužiti za odgovarajuće intervencije u uređenje instituta de lege ferenda. Zapravo za takvo propisivanje iznimke od osnovnog pravila kojim bi bili obuhvaćeni svi slučajevi u kojima bi do povlačenja tužbe došlo zato što je nastavljanje vođenja parnice postalo bespredmetno iz razloga koje je skrivio tuženik ili do kojih je došlo zbog slučaja koji mu se dogodio i iz razloga za čiji je nastanak on dao povod, koji bi mu se mogli pripisati. To se pokušalo postići Novelom 19 novoredigiranom odredbom stavka 2. članka 158. ZPP 19.

\subsection{Značenje pojma „povlačenje tužbe”}

\subsubsection{Uvod}

Do nastupanja pravne posljedice povlačenja tužbe, do toga da će se tužba smatrati povučenom, može doći u povodu eksplicitne izjave tužitelja o tome, ali i, neovisno o tome, nastupanjem određenih okolnosti za koje Zakon veže nastupanje te pravne posljedice.

U povodu izričite izjave tužitelja da povlači tužbu ne mora uvijek doći do toga da se tužba smatra povučenom, takva izjava, naime, da bi kao takva dovela do te pravne posljedice, mora biti dana do određenog momenta u razvitku parnice, nakon kojega je za nastupanje te posljedice potrebna i suglasnost tuženika (arg. ex 193., v. infra ad 2.2.2.).

Do nastupanja pravne posljedice povlačenja tužbe može, međutim, doći i u povodu određenih okolnosti uz koje Zakon veže nastanak te posljedice (predmnijevano povlačenje tužbe) (v. infra ad 2.2.3.). ${ }^{11}$

Pravila o naknadi troškova postupka u slučaju povlačenja tužbe u osnovi se jednako primjenjuju u oba navedena slučaja u kojima je nastupila pravna posljedica povlačenja tužbe. ${ }^{12}$

tražiti naknadu troškova od protivnika, trebala samo dokazati da nije dala povod za pokretanje parnice. Za razliku od odredbe članka 157. ZPP-a, prijašnja se odredba reč. 2. stavka 1. članka 158. ZPP 13 temeljila (jednako kao što se i odredba važećeg stavka 2. članka 158. ZPP 19 temelji) na načelu dokazanog davanja povoda za parnicu - da bi tužitelj bio ovlašten tražiti naknadu troškova od tuženika, nije bilo dostatno (i nije dostatno) da dokaže da nije dao povod za parnicu, već je bio dužan (i, i dalje, jest dužan) dokazati da je povod za nju dao tuženik.

11 O povlačenju tužbe usp. Mihajlo Dika, Građansko parnično pravo, Tužba, 6. knjiga. (Zagreb: Narodne novine, 2009.), §§ 54.-56.

12 U tom smislu i Poznić, Komentar Zakona o parničnom postupku, 342. 
Ono što je rečeno o pravu stranaka u slučaju povlačenja tužbe vrijedilo bi i u slučaju povlačenju protutužbe. ${ }^{13}$ U slovenskoj doktrini, s obzirom na uređenje prema ZPP-a iz 1999., koji se kad je riječ o odredbama koje se tiču naknade troškova u slučaju povlačenja tužbe sadržajno i numerički podudarao s hrvatskim ZPP 13., istaknuto je da kada tužitelj povuče tužbu, mora tuženiku naknaditi sve parnične troškove koji su nastali u vezi s tužbom ili u povodu tužbe, ali ne i troškove koje je tuženik imao u vezi s možebitnom protutužbom; da u praksi nisu tako rijetki slučajevi da tužbu odnosno protutužbu povuku i tužitelj i tuženik; da se mora tada postupati po stavku 1. članka 158. SL ZPP-a i pritom uzeti u obzir vrijednost povučene tužbe, odnosno protutužbe. ${ }^{14}$

\subsubsection{Povlačenje tužbe u povodu izričite izjave tužitelja}

Izraz ,povlačenje tužbe” u kontekstu odredbe stavka 1. članka 158. ZPP 19 treba razumjeti u smislu dispozicije, izričite izjave tužitelja da povlači tužbu u povodu koje je došlo do nastupanja pravne posljedice povlačenja tužbe, do pravne situacije u kojoj se smatra da tužba nije ni bila podnesena (193/9.). ${ }^{15}$ Naime, izjava tužitelja da povlači tužbu ne dovodi uvijek, kako je to već supra ad 2.2.1. rečeno, do toga da se ona smatra povučenom. Tužitelj može povući tužbu bez pristanka tuženika sve dok se on nije upustio u raspravljanje o glavnoj stvari (193/1.). Nakon što se tuženik upustio u raspravljanje o glavnoj stvari tužitelj je može povući do zaključenja glavne rasprave uz tuženikovu izričitu ili prešutnu suglasnost (193/2.), a nakon toga uz njegovu izričitu suglasnost sve do pravomoćnosti odluke kojom se postupak pred sudom drugog stupnja dovršava (193/3.). Ako se tuženik usprotivi povlačenju tužbe kad je na to ovlašten, tužba se ne smatra povučenom i parnica se nastavlja kao da tužitelj nije ni izjavio da povlači tužbu (arg. ex 193/1., 2.). U tom bi se slučaju tužitelj, koji se više ne bi želio parničiti, morao odreći tužbenoga zahtjeva i tako stvoriti uvjete za donošenje presude na temelju odricanja (331.a). U njoj bi sud o troškovima postupka trebao odlučiti po općim pravilima, osim ako bi se tužitelj odrekao tužbenoga zahtjeva nakon što bi tuženik ispunio utuženu obvezu ili zbog drugih razloga koji bi se mogli pripisati tuženiku (158/2.; v. infra ad 3.). Ako se tužitelj ne bi odrekao tužbenog zahtjeva, parnica bi se morala okončati kontradiktornom meritornom odlukom, kojom bi, ovisno o tome tko bi prema toj odluci izgubio parnicu, na naknadu troškova mogli biti osuđeni i tužitelj i tuženik.

Supra izloženo određenje pojma ,povlačenje tužbe“" relevantno je i u slučaju u kojemu tužitelj koji je povukao tužbu ima pravo tražiti naknadu troškova postupka od tuženika (158/2., v. infra ad 3.).

13 Usp Poznić, Komentar Zakona o parničnom postupku, 342.

14 Usp. Betteto, Pravdni postopek, Zakon s komentarjem, 2. knj, 48.

15 O potrebi razlikovanja između izjave o povlačenju tužbe kao parnične radnje tužitelja i nastupanju pravne posljedice povlačenje tužbe u povodu takve izjave usp. Dika, Građansko parnično pravo, Tužba, 6. knjiga, § 54/1. 


\subsubsection{Presumirano povlačenje tužbe}

Do presumiranoga povlačenja tužbe dolazi ako Zakon za određena ponašanja stranaka, redovito tužitelja, ili izostanka nekih njihovih inicijativa veže nastupanje pravne posljedice povlačenja tužbe, dakle, ne predmnjeve o tome da je tužitelj dao izjavu da povlači tužbu, već predmnjeve da se smatra kao da tužba nije ni bila podnesena (193/9.). ${ }^{16}$

O postavljanju zahtjeva za naknadu troškova postupka u slučaju pretpostavljenoga povlačenja tužbe v. infra ad 5.

O djelomičnom povlačenju tužbe v. infra ad 2.3. i 3.5.

\subsubsection{Povlačenje tužbe promjenom istovjetnosti zahtjeva}

Do implicitnog povlačenja tužbe dolazi i u slučaju njezine preinake zamjenom izvorno istaknutog zahtjeva novim. ${ }^{17}$ Takva preinaka dovodi do povlačenja izvorno postavljenog zahtjeva i njegove zamjene novoistaknutim. Upravo se zato i postavlja pitanje troškova postupka nastalih prije takve preinake, troškova postupka nastalih $\mathrm{u}$ povodu izvorno podnesene tužbe prije nego što je došlo do njezine preinake promjenom istovjetnosti zahtjeva. Budući da preinaka o kojoj je riječ implicira i svojevrsno povlačenje tužbe, na te bi troškove trebalo primijeniti opća pravila o naknadi troškova u slučaju povlačenja tužbe. To znači da bi tužitelj u pravilu bio dužan tuženiku naknaditi troškove postupka koji bi bio proveden do preinake (158/1., v. supra ad 2.2.2.). Međutim, ako bi tuženik svojim ponašanjem dao povoda za preinaku, npr. time što bi uništio stvar čija je predaja utužena, zbog čega bi tužitelj preinačio svoj izvorni zahtjev za predaju te stvari u zahtjev za naknadu štete koju je zbog toga pretrpio, tuženik bi bio dužan naknaditi troškove toga postupka, budući da bi svojim ponašanjem dao povoda za njihov nastanak, ako bi se prejudicijalno utvrdilo da je tužiteljev izvorni zahtjev na predaju stvari bio osnovan.

O reperkusijama moguće analogne primjene odredaba članka 154. stavka 2. ZPP 19 u slučaju smanjenja tužbenog zahtjeva v. infra ad 2.3.

16 Prema Zakonu do pretpostavljenog povlačenja tužbe može, između ostaloga, doći u povodu: neudovoljavanja pozivu za ispravak tužbe (109/4.); zastoja postupka zbog pokušaja mirnog rješenja spora (186.g/3.); neopravdanog izostanka stranaka s pripremnog ročišta (291.); neopravdanog izostanka stranaka s ročišta za glavnu raspravu (295.); nepodnošenja prijedloga za donošenje dopunske presude u roku (339/2.); izostanka tužitelja s ročišta u sporovima male vrijednosti (465.).

17 Preinaka tužbe jest promjena istovjetnosti zahtjeva, povećanje postojećeg ili isticanje drugog zahtjeva uz postojeći (191/1.). Do promjene istovjetnosti zahtjeva može doći isticanjem novog zahtjeva koji bi se sadržajno nominalno razlikovao od izvornog kojim je zamijenjen, ali i promjenom činjenične osnove kojom bi se izmijenio i identitet pravnog odnosa s obzirom na koji je bio istaknut zahtjev koji bi nominalno sadržajno ostao neizmijenjenim, čime bi bio izmijenjen i identitet samog zahtjeva. Npr. ako bi tužitelj izjavio da svoj zahtjev za isplatu određenog iznosa novca ne temelji više na tvrdnji da je tuženiku dao određeni iznos novca s time da je ovaj izjavio da će mu ga vratiti u određenom roku, dakle na činjeničnoj osnovi ugovora o zajmu, već na tvrdnji da mu je tuženik utuženi novac duguje za stvar koju mu je prodao, dakle, na činjeničnoj osnovi ugovora o kupoprodaji. O preinaci tužbe preinakom činjenične osnove istaknutog zahtjeva usp. Dika, Građansko parnično pravo, Tužba, 6. knjiga, § 50/2.2.4. 
O postavljanju zahtjeva za naknadu troškova u ovom slučaju povlačenja tužbe v. infra ad 5 .

\subsection{Smanjenje tužbenog zahtjeva}

\subsubsection{Osnovno pravilo}

Ako tužitelj smanji tužbeni zahtjev, tuženik ima pravo na naknadu parničnih troškova razmjerno visini smanjenoga dijela tužbenog zahtjeva ${ }^{18}$ u skladu s odredbom koja uređuje naknadu troškova u slučaju povlačenja tužbe $(158 / 1),.{ }^{19}$ i zbog toga što smanjenje tužbenog zahtjeva, koje se po Zakonu ne smatra preinakom tužbe (arg. ex 191/3.), ima značenje djelomičnoga povlačenja tužbe. ${ }^{20}$ Pritom, budući da smanjenje tužbenog zahtjeva ima značenje djelomičnog povlačenja tužbe, pri odlučivanju o troškovima postupka trebalo bi u načelu voditi računa o vrijednosti predmeta spora u vrijeme poduzimanja svake parnične radnje. Zbog toga bi i kod smanjenja tužbenog zahtjeva trebalo primijeniti pravila koja vrijede za naknadu troškova u slučaju povlačenja tužbe. ${ }^{21}$ Stoga, ako se vrijednost predmeta spora mijenja tijekom postupka, visina parničnih troškova koji se sastoje od nagrada za rad punomoćnika - odvjetnika utvrđuje se za svaku parničnu radnju koju je on poduzeo prema vrijednosti predmeta spora u vrijeme njezina poduzimanja, a ne prema visini konačno postavljenoga zahtjeva. ${ }^{22}$ Ovo se pravno shvaćanje tiče slučajeva u kojima je vrijednost predmeta

18 Smanjiti se po prirodi stvari može samo kvantitativno određeni tužbeni zahtjev, redovito zahtjev koji bi se ticao isplate određenog iznosa novca. Usp. Dika, Građansko parnično pravo, Tužba, 6. knjiga, $\S 51 / 2$.

19 ŽS ZG: Gž-8126/01 - ING PSP 2003-8-119. Tako i Poznić, Komentar Zakona o parničnom postupku, 342, pozivajući se na Hans W. Fashing, Kommentar zu den Zivilprozessgesetzen (Wiena: II.B., 1962.), 339.

20 Usp.: Siniša Triva i Mihajlo Dika, Građansko parnično procesno pravo (Zagreb: Narodne novine, 2004.), 430; Dika, Građansko parnično pravo, Tužba, 6. knj., §§ 51/2, 55/1.

21 U tom smislu VSRH: Revr-1426/2010-2 - IO VSRH 2/2011-200., pozivajući, uz ostalo, i na svoje odluke broj Revt-35/2004, Rev-402/2004 i Rev-5231/2005.

22 Tako i VSRH: Rev-2080/91 - IO 1993/25; Rev-1090/92 - IO 1994/287. V. i Ivo Grbin, „Vrijednost predmeta spora te troškovi parničnog postupka”, u: Godišnjak 14., Aktualnosti hrvatskog zakonodavstva i pravne prakse (Zagreb: Organizator, 2007.), 457. U predmetu broj Rev-2080/91 Vrhovni sud se zapravo opredijelio za načelo monetarnog nominalizma u određivanju vrijednosti predmeta spora kao mjerodavnom za određivanje naknade troškova: „U reviziji se iznosi shvaćanje da je bez obzira na preinačenje tužbenog zahtjeva u tijeku spora povećanjem iznosa tražene naknade štete, a što da je učinjeno zbog pada vrijednosti novca, u stvari bila realno uvijek ista vrijednost predmeta spora Revizija nije osnovana. // Odluka drugostupanjskog suda o naknadi troškova postupka rezultat je, po nalaženju ovog suda, pravilnog pristupa stvari. Naime, prema odredbi čl. 151. st. 2. ZPP (...) parnični troškovi obuhvaćaju i nagradu za rad odvjetnika, s tim da se suglasno odredbi st. 2. čl. 155. ZPP nagrada za rad odvjetnika i naknada troškova, jer je propisana Tarifom određuje prema Tarifi. // Prema Tarifi (Narodne novine, br. 16/90), koja je bila na snazi u vrijeme donošenja prvostupanjske odluke o troškovima postupka, određeno je da odvjetniku pripada naknada za određene procesne radnje u parničnom postupku ovisno o vrijednosti spornog predmeta (Tbr. 7.), dakle ovisno o vrijednosti predmeta spora, s tim da je nagrada iskazana brojem bodova ovisno o vrijednosti spornog predmeta. // Odredbom Tbr. 48. st. 3. propisano je da kada sud ili drugi organ odlučuje 
spora tijekom prvostupanjskog postupka sukcesivno povećavana.

Suđeno je da je u slučaju smanjenja tužbenoga zahtjeva tijekom postupka za utvrđivanje vrijednosti predmeta spora radi obračuna prava tužitelja na naknadu troškova za zastupanje mjerodavna konačno postavljena visina tužbenoga zahtjeva. ${ }^{23}$ Tuženik bi imao pravo obračunavati naknadu za troškove zastupanja prema vrijednosti predmeta spora u vrijeme poduzimanja pojedine radnje. Budući da smanjenje

o naknadi troškova zastupanja na teret protivne stranke, primjenjuje tarifu i vrijednost boda koja je na snazi u vrijeme donošenja odluke. // Dakle, suglasno navedenoj stavci dan donošenja sudske odluke mjerodavan je za opredjeljenje koja će se Tarifa primijeniti i koja je vrijednost boda, a ne koja će se vrijednost spornog predmeta uzeti kao mjerodavna radi utvrđivanja broja bodova za pojedine obavljene radnje. O kojoj je pak vrijednosti predmeta spora riječ radi obrade troškova kategorija je procesnog prava, a u svakom slučaju kad je predmet tužbenog zahtjeva određeni novčani iznos (u konkretnom slučaju riječ je o zatraženoj naknadi štete) vrijednost predmeta spora je upravo utužena novčana svota. // Broj bodova, kad je tužbeni zahtjev izražen u novčanom iznosu, ovisi o visini novčanog iznosa u Tarifi postavljenog u relacijama od dinara - dinara, pa stoga upravo u konkretnom slučaju ovisno o visini tužbenog zahtjeva koji je bio predmet raspravljanja u pojedinim fazama parničnog postupka ovisi i utvrđivanje broja bodova kao temelja za utvrđivanje visine nagrade koja za poduzete radnje u parničnom postupku pripada odvjetniku. // Drugim riječima, u Tarifi, posebno u Tbr. 48. st. 3., kao niti u odredbama ZPP-a (posebno što povećanje tužbenog zahtjeva u procesnom smislu znači preinačenje tužbe - 191. st. 1. ZPP) nema temelja za zaključak da se broj bodova za pojedine procesne radnje (npr. tužba ili zastupanje) utvrđuje prema visini konačno postavljenog tužbenog zahtjeva, što smatra pravilnim revizija ocjenjujući da je povišenje tužbenog zahtjeva „rezultat pada vrijednosti novca i promjena kriterija za utvrđivanje naknade“. Dakle, drugostupanjski je sud, po nalaženju ovog suda, pravilnim pristupom odlučio o visini troškova parničnog postupka koje je obvezna platiti protivna stranka“. O ovoj odluci v. i Branko Hrvatin, „Naknada troškova parničnog postupka“, Hrvatska gospodarska revija (1996.), 1308-1309. Načelo monetarnog nominalizma potvrđeno je i u judikatu VSRH: Revt-245/2011-2 - IO VSRH 2/2011-198., prema kojemu je kod obračuna visine troškova zastupanja mjerodavna vrijednost predmeta spora u vrijeme poduzimanje pojedine parnične radnje, pri čemu okolnost da je za vrijeme trajanja postupka došlo do denominacije domaće valute (dinari u HRD-e, a potom u kune) i do smanjenja vrijednosti novca ne utječe na visinu nadoknade parničnog troška, između ostaloga i zato što su iznosi nagrade prema Odvjetničkoj tarifi bili propisani.

23 ŽS ZG: Gž-3451/96; Gž-3422/96 (cit. prema Hrvatin, „Naknada troškova parničnog postupka“, u bilj. 17, 1309-1310). U konkretnom slučaju Županijski sud u Zagrebu je zauzeo stav da se visina troškova parničnih radnji tužitelja a koji se sastoje od nagrade za rad odvjetnika, ima utvrđivati prema vrijednosti predmeta spora konačno postavljenog tužbenog zahtjeva, a ne prema vrijednosti predmeta spora u vrijeme kada je pojedina radnja poduzimana. Za razliku od prvostupanjskog suda koji je troškove zastupanja po odvjetniku odredio prema vrijednosti predmeta spora u vrijeme kada je pojedina radnja poduzimana. Prema odluci drugostupanjskog suda, ,smanjenje tužbenog zahtjeva ne predstavlja preinačenje tužbe (čl. 191. st. 3. ZPP). Kada tužitelj smanji tuženi zahtjev, ta procesna dispozicija ima učinak povlačenja tužbe (tužba se može povući i samo djelomično - smanjenjem tužbenog zahtjeva), a povučena tužba smatra se kao da nije niti podnesena. "Navedeni učini povlačenja tužbe u razrješenju spornog pitanja: koja vrijednost predmeta spora u ovom slučaju predstavlja temelj za odmjeru troškova zastupanja tužitelja po odvjetniku - znači da vrijednost predmeta spora predstavlja onaj glavni zahtjev (čl. 35. st. 1. i čl. 37. st. 2. ZPP-a) koji je tužitelj konačno postavio. Stoga je za odmjeru ovog parničnog troška potpuno irelevantno što je vrijednost predmeta spora većim dijelom parnice bila znatno viša“". 
tužbenoga zahtjeva ima značenje svojevrsnog povlačenja tužbe ${ }^{24}$ pri odlučivanju o naknadi troškova postupka u slučaju smanjenja tužbenoga zahtjeva trebalo bi na odgovarajući način primijeniti i pravila o naknadi troškova u slučaju (djelomičnoga) povlačenja tužbe (158/1.). To znači da bi tuženik imao pravo na naknadu troškova za smanjeni dio tužbenoga zahtjeva za parnične radnje poduzete prije smanjenja prema kriteriju (djelomičnoga) uspjeha u parnici (154/2.), osim ako do smanjenja ne bi došlo nakon što je tuženik djelomično udovoljio zahtjevu tužitelja ili iz drugih razloga koji bi mu se mogli pripisati (158/2.). U slučaju sniženja pa povećanja tužbenoga zahtjeva trebalo bi kombinirati rješenja predviđena za odlučivanje o naknadi troškova u slučaju sniženja i u slučaju povećanja tužbenog zahtjeva i time uvjetovanog smanjenja, odnosno povećanja vrijednosti predmeta spora. ${ }^{25}$ Pritom za obračun visine nagrade ne bi bila mjerodavna vrijednost predmeta spora utvrđena prema ZSP-u, ${ }^{26}$ već prema pravilima ZPP-a o utvrđivanju te vrijednosti (35., v. § ). ${ }^{27}$

O stajalištu sudske prakse o naknadi troškova postupka u slučaju smanjenja tužbenog zahtjeva kad ono nema za posljedicu manju nagradu za zastupanje propisanu Odvjetničkom tarifom v. infra ad 2.3.2.

\subsubsection{Sniženje tužbenog zahtjeva na zahtjev za naknadu troškova postupka}

Kad tužitelj smanji tužbeni zahtjev na zahtjev za naknadu troškova postupka, ${ }^{28}$ on zapravo povlači glavni tužbeni zahtjev i svoj zahtjev za naknadu troškova postupka pretvara u glavni zahtjev. Nakon takvog smanjenja tužbenog zahtjeva u mogućem nastavljenom postupku u kojemu bi se odlučivalo o osnovanosti zahtjeva tužitelja za naknadu troškova postupka, npr. zato što bi radi utvrđivanja pretpostavaka o ispunjenju kojih bi ovisilo pravo tužitelja na naknadu troškova postupka trebalo izvoditi neke dokaze, odnosno čak i rješavati prejudicijalna pitanja, npr. je li utužena tražbina tužitelja uopće postojala, kad je dospjela i kad ju je tuženik ispunio, javilo bi se i pitanje ne samo prava na naknadu troškova prije povlačenja tužbe, već i prava na naknadu troškova toga nastavljenog postupka. Za prosuđivanje tih troškova, troškova postupka u kojemu treba odlučiti o zahtjevu koji je reduciran na zahtjev za naknadu troškova prethodno provedenog postupka, vrijedila bi opća pravila o predujmljivanju i konačnom snošenju troškova postupka.

24 Tako i ŽS ZG: Gž-3451/96, v. prethodnu bilj.

25 ŽS ZG: Gž-3422/96, cit.

26 ZSP: Zakon o sudskim pristojbama, Narodne novine, br. 74/95., 57/96., 137/02., (26/03.), 125/11., 112/12., 157/13., 110/15.

27 ŽS BJ: Gž-1448/00 - IO 1/01-176.

28 U tom smislu Poznić, Komentar Zakona o parničnom postupku, 343, ako je tuženik u cijelosti udovoljio tužbenom zahtjevu. Prema ovom autoru, koji se glede toga poziva na judikaturu, tužitelju nije dopušteno da radi „,dosuđenja tog traženja“ stavi zahtjev za utvrđenje da je prvobitno istaknuti (glavni, ispunjeni) zahtjev bio osnovan, i to stoga što pravo tužitelja na naknadu troškova u povodu ispunjenja obveze tijekom spora ne ovisi o tome je li obveza tuženika bila osnovana. Sud, dakle, nije dužan prije nego što odluči o troškovima, ispitivati je li tužitelju odista pripadalo ono subjektivno pravo za koje je glavnim zahtjevom tražio zaštitu. Uostalom, ističe autor, osnovanost tužbenog zahtjeva utvrđuje se po provedenoj raspravi, a sud donosi rješenje o prestanku litispendencije čim tužitelj poslije ispunjenja obveze povuče tužbu. 
U judikaturi je izraženo stajalište da je tužitelj koji je snizio tužbeni zahtjev na parnični trošak zapravo u cijelosti povukao tužbu jer Zakonom nije predviđena mogućnost sniženja tužbenoga zahtjeva na parnični trošak. ${ }^{29} \mathrm{~S}$ tim se shvaćanjem treba složiti uz ogradu da tužitelj u slučaju o kojemu je riječ nije u cijelosti povukao tužbu, već je to učinio samo u odnosu na glavni zahtjev, ali ne i u odnosu na sporedni zahtjev za naknadu troškova postupka. U tom se slučaju izraz povlačenje tužbe u kontekstu odredaba stavaka 1. i 2. ZPP 19 odnosi samo na povlačenje glavnog zahtjeva, ali ne i sporednog zahtjeva na traženje naknade troškova postupka. ${ }^{30}$

Kad tužitelj izjavi da povlači tužbu, trebalo bi iz sadržaja te izjave, odnosno na temelju okolnosti konkretnoga slučaja izvesti tiče li se ta izjava samo glavnog zahtjeva ili i zahtjeva za naknadu troškova postupka, odnosno svodi li tužitelj danom izjavom svoje zahtjeve na zahtjev za naknadu troškova postupka. Ako tužitelj, koji je izjavio da povlači tužbu, ne bi istodobno zatražio i naknadu troškova postupka od tuženika, trebalo bi, osim ako okolnosti konkretnoga slučaja ne bi upućivale na drukčiji zaključak, uzeti da on ne traži naknadu troškova postupka, odnosno, ako je tijekom postupka sukcesivno postavljao zahtjeve za naknadu pojedinih troškova, da je time povukao i te zahtjeve - svakako uz uvjet da u povodu takve njegove izjave nastupi pravna posljedica povlačenja tužbe i odnosu na sporedni zahtjev za naknadu troškova postupka.

\subsubsection{Smanjenje tužbenog zahtjeva u slučaju u kojemu to smanjenje nema za posljedicu manju nagradu za zastupanje propisanu Odvjetničkom tarifom}

\subsubsection{Stajalište sudske prakse prije Novele 19}

Vrhovni sud je prema uređenju troškovnog prava prije Novele 19 u pogledu prava tuženika da traži naknadu troškova postupka u slučaju smanjenja tužbenog zahtjeva zauzeo pravno shvaćanje da se o tim troškovima odlučuje ,prema uspjehu stranaka u sporu u odnosu na vrijednost predmeta spora smanjenog tužbenog zahtjeva, s time da tuženiku pripada pravo na naknadu troškova koje je imao u vezi s dijelom tužbenog zahtjeva koji je smanjen neovisno o uspjehu u sporu, jer smanjenje tužbenog zahtjeva u biti predstavlja povlačenje tužbe u odnosu na smanjeni dio tužbenog zahtjeva, ali to samo u slučaju ako bi troškovi izračunati prema vrijednosti predmeta spora prijašnjeg zahtjeva bili veći od troškova izračunatih prema vrijednosti smanjenog tužbenog zahtjeva“ ${ }^{31}$ Podudarno s navedenim judikatom suđeno je da ako smanjenje tužbenog

29 VSH: Rev-644/98 - INF-N 4874/00.

30 To bi osobito došlo do izražaja ako bi u povodu zahtjeva za naknadu troškova bilo potrebno provesti nastavni postupak u kojemu bi se provjeravala njegova osnovanost, postupak u kojemu bi mogli nastati dodatni troškovi. U tom bi slučaju sud trebao odlučiti o ,glavnom” zahtjevu za naknadu troškova prethodno provedenog postupka te o ,sporednom” zahtjevu za naknadu troškova tog nastavljenog postupka.

31 VSRH: Rev-2603/2011 - IO VSRH 2/2014-180. (odluka od 19.2.2013.), pozivajući se na svoje odluke broj Revr-1428/209-2 od 27.10.2010. i Rev-402/04-2 od 21.9.2005. Takvo je stajalište Vrhovni sud zauzeo jer u ,konkretnom slučaju smanjenje tužbenog zahtjeva nije bilo od utjecaja na visinu troškova zastupanja stranaka po odvjetniku, jer je prema Tarifi o nagradama i naknadi troškova za rad odvjetnika visina naknade u odnosu na smanjeni tužbeni zahtjev od 15.140,00 
zahtjeva nema za posljedicu manju nagradu za zastupanje propisanu odvjetničkom tarifom, uspjeh stranaka u parnici treba ocijeniti sagledavajući postupak u cjelini, da ne treba razlučivati pojedinačni uspjeh u sporu do djelomičnog smanjenja zahtjeva i uspjeh nakon toga. ${ }^{32}$

Treba posumnjati u pravilnost takva stajališta, ${ }^{33}$ i to i prema uređenju troškovnog prava s obzirom na koje je ono zauzeto i s obzirom na uređenje toga prava nakon Novele 19, kojom su izmijenjene odredbe članka 154. ZPP-a o naknadi troškova u slučaju potpunog i djelomičnog uspjeha u parnici.

\subsubsection{Kritika prakse sudova s aspekta uređenja troškovnog prava prije Novele 19}

Prije Novele 2019 osnovno je pravilo o naknadi troškova postupka u slučaju djelomičnog uspjeha u parnici glasilo:

Ako stranka djelomično uspije u parnici, sud može ${ }^{34}$ s obzirom na postignuti uspjeh, odrediti da svaka snosi svoje troškove ili da jedna stranka nadoknadi drugoj stranci i umješaču razmjeran dio troškova. ${ }^{35}$ (154/2. ZPP 13).

Kriterij od koga je trebalo polaziti prema navedenom pravilu bio je uspjeh u parnici, a ne iznos troškova pojedinih radnji, uključujući i iznos naknade za sudske pristojbe, za odvjetničko zastupanje u vezi s njihovim poduzimanjem i za izvođenje

kn ista u odnosu na prijašnji zahtjev istaknut u tužbi u iznosu od 41.000,00 kn“. Na ovaj se judikat referira i Vladimir Vučković, „Troškovi parničnog postupka kod smanjenja tužbenog zahtjeva - kritika stava Vrhovnog suda Republike Hrvatske", Hrvatska pravna revija, br. 12 (2016.), pod 2.2.3.

U odluci od 22. siječnja 2013. broj Revr-127/11-2, u predmetu u kojemu je tužbeni zahtjev smanjen s 82.492,50 kn na 13.492,50 kn, a prihvaćen u iznosu od 12.148,50., Vrhovni sud je, pozivajući se na odluku broj Revr-1428/2009-2 od 27. listopada 2010., istaknuo da „okolnost smanjenja tužbenog zahtjeva nije bila od utjecaja na visinu troškova zastupanja jer je prema Tarifi o nagradama i naknadi troškova za rad odvjetnika visina naknade za zastupanje u odnosu na smanjeni tužbeni zahtjev od 13.492,50 kn ista kao i u odnosu na prijašnji zahtjev od $82.492,50$ kn“. Cit. prema Vučković, „Troškovi parničnog postupka kod smanjenja tužbenog zahtjeva - kritika stava Vrhovnog suda Republike Hrvatske".

U odluci od 27.10.2010., broj Revr-1428/2009.2., Vrhovni sud je, potvrđujući odluku drugostupanjskog suda, supra izloženo pravno shvaćanje opravdao time da „u konkretnoj pravnoj stvari odluka drugostupanjskog suda nije utemeljena na shvaćanju koje ne bi bilo podudarno s tim shvaćanjem, jer iako se vrijednost predmeta spora mijenjala u postupku, tako da je u trenutku podnošenja tužbe iznosila $84.435,60$ kn sve do preciziranja i povlačenja tužbenog zahtjeva u podnesku od 9. ožujka 2006., kada vrijednost predmeta spora iznosi 54.143,20 kn, ona nije bila od utjecaja na određivanje parničnog troška sukladno Tarifi o nagradama i naknadi troškova za rad odvjetnika (Narodne novine, br. 91/04, 37/05, 59/07).“ Cit. prema Vučković, „Troškovi parničnog postupka kod smanjenja tužbenog zahtjeva - kritika stava Vrhovnog suda Republike Hrvatske".

32 ŽS ST: Gžnš-383/2012 - IO VSRH 1/2014.-197. 154/2.

33 O kritici ovog stajališta sudske prakse, koja se u bitnome podudara s ovdje zauzetim stavovima o toj praksi, usp. i Vučković, „Troškovi parničnog postupka kod smanjenja tužbenog zahtjeva - kritika stava Vrhovnog suda Republike Hrvatske", pod 3.

34 Riječ „može“ u kontekstu ove odredbe treba razumjeti u smislu „u pravilu treba“.

35 Pojedine riječi u tekstu citirane odredbe naglasio M.D. 
pojedinih dokaza. Kriteriji za određivanje navedenih naknada bili su mjerodavni za utvrđivanje njihove visine, a ne za utvrđivanje prava na njihovu naknadu. To znači da je prema prije važećem uređenju, nakon što bi se utvrdili troškovi koje su stranke imale po određenim osnovama, npr. za sudske pristojbe, za odvjetničko zastupanje, za izvođenje dokazivanja itd., najprije trebalo utvrditi njihovo pravo na naknadu tih troškova - prema kriteriju uspjeha u parnici, a nakon toga tako dobivene iznose prebiti i neprebijeni višak dosuditi stranci kojoj je pripadao. Budući da se uspjeh u parnici prosuđivao (i, nakon Novele 19 - prosuđuje) prema vrijednosti glavnoga zahtjeva (arg. ex 35/1., 40.), uspjeh u sporu trebao se prosuđivati prema tome u kojem je postotku taj zahtjev prihvaćen.

U slučaju smanjenja tužbenog zahtjeva kao svojevrsnog povlačenja tužbe, ${ }^{36}$ pravo tuženika da traži naknadu troškova trebalo je odvojeno prosuđivati za radnje koje su bile poduzete prije i nakon smanjenja. Za radnje prije smanjenja trebalo je, nakon što bi se utvrdila visina troškova koje je u povodu tih radnji imala svaka od stranaka i nakon što bi se primjenom u praksi prije Novele 19 prihvaćene metode obračuna troškova izvršio obračun tih troškova, pravo na naknadu troškova za te radnje priznati stranci kojoj je pripadao neprebijeni višak. To znači da je najprije trebalo utvrditi u apsolutnom iznosu (potrebne - 155.) troškove koje je svaka od stranaka imala u postupku prije smanjenja tužbenog zahtjeva, a zatim uzeti u obzir u kojoj je mjeri svaka od njih uspjela u parnici u odnosu na te troškove. Pritom je trebalo, s jedne strane, voditi računa o tome da tužitelj nije uspio u dijelu u kojemu je smanjio izvorno postavljeni zahtjev, a, s druge strane, o tome je li i u kojoj mjeri konačnom odlukom prihvaćen smanjeni zahtjev. Ako bi i smanjeni tužbeni zahtjev bio odbijen, tužitelj ne bi imao pravo na naknadu troškova - pravo tražiti naknadu svojih troškova imao bi samo tuženik (arg. ex 154/1.). Ako bi, međutim, smanjeni zahtjev bio prihvaćen, konačni se uspjeh u parnici trebao prosuđivati ovisno o visini tog preostalog zahtjeva u odnosu na izvorno istaknuti zahtjev. Pritom je trebalo odvojeno izračunavati i obračunavati troškove stranaka do smanjenja i nakon njega. Ako bi tužitelj izvorno bio utužio iznos od $100.000,00 \mathrm{kn}$, a zatim taj zahtjev smanjio na 20.000,00 kn, koji mu je iznos bio dosuđen, valjalo je zaključiti da je tužitelj u parnici do smanjenja zahtjeva uspio s $20 \%$, a tuženik s $80 \%$. Nakon toga trebalo je, prema supra prije Novele 19 u praksi prihvaćenoj metodi obračuna troškova, utvrditi apsolutne iznose tih $20 \%$ troškova tužitelja i $80 \%$ troškova tuženika nastalih do smanjenja tužbenog zahtjeva, zatim prebiti te iznose i iznos koji bi za jednu od stranaka preostao nakon tog prijeboja, uzeti u obzir pri konačnom obračunu troškova. Nakon što bi bilo utvrđeno tko kome što duguje za dionicu postupka prije smanjenja, trebalo je za dionicu nakon toga posebno utvrditi i obračunati troškove stranaka s obzirom na smanjeni iznos tužbenog zahtjeva. Završno je trebalo uzeti neprebijeni iznos koji je preostao jednoj od stranaka nakon obračuna troškova za dionicu postupka prije smanjenja zahtjeva i neprebijeni iznos koji je preostao jednoj od stranaka za dionicu postupka nakon smanjenja. Ako ne bi bila riječ o istoj stranci, trebalo je prebiti te iznose i neprebijeni višak dosuditi stranci koja bi na njega imala pravo. Pri izračunavanju ukupnog iznosa

36 O stavu sudske prakse da smanjenje tužbenog zahtjeva ima značenje djelomičnog povlačenja tužbe v. bilj. 15 . 
troškova pojedinih od stranaka za svaku od dionica postupka prije njihova obračuna, troškove na osnovi odvjetničkog zastupanja trebalo je uzimati u obzir pri utvrđivanju ukupne mase troškova pojedine stranke - odvojeno za svaku dionicu postupka.

Stajalište Vrhovnog suda utemeljeno je na zamjeni navedenih kriterija koje je trebalo sukcesivno primjenjivati pri obračunu troškova postupka. ${ }^{37}$ Prema tom stajalištu za naknadu nije bio mjerodavan razmjeran uspjeh u parnici, već to jesu li pojedini troškovi s obzirom na zahtjev prije njegova smanjenja i nakon toga bili isti ili različiti. Pritom je visina zahtjeva prije i nakon smanjenja bila irelevantna ako bi ti troškovi s obzirom na kriterije za njihovo izračunavanje bili isti neovisno o toj visini. To znači da je tužitelj, prema tom stajalištu, imao pravo na naknadu troškova za pristojbe, za izvođenje dokazivanja i za odvjetničko zastupanje neovisno o tome je li i koliko smanjio tužbeni zahtjev (djelomično povukao tužbu), ako bi ti troškovi bili isti prije i nakon poduzimanja te radnje.

Izloženo shvaćanje Vrhovnog suda omogućavalo je tužiteljima da ističu neprimjereno visoke tužbene zahtjeve, onda kad su propisi o sudskim pristojbama i Odvjetnička tarifa to dopuštali. Pritom računajući s time da se takvim postupanjem ne izlažu riziku da će zbog toga protivniku morati naknaditi troškove postupka prema kriteriju uspjeha u parnici. Posljedice „otvaranja“ takve mogućnosti bile su vrlo ozbiljne. Naime, budući da se vrijednost predmeta spora određivala (i, nakon Novele 19, i dalje određuje) kod novčanih zahtjeva prema visini glavnog novčanog zahtjeva (35/1., 40/1.), tužitelj je postavljanjem neprimjereno visokog tužbenog zahtjeva, ali u granicama u kojima o tome nije ovisilo određivanje visine nagrade za odvjetničko zastupanje itd., mogao utjecati na izbor vrste postupka koji će se provesti. Primjerice da se postupak provodi po pravilima o redovnom parničnom postupku, a ne po postupku u sporovima male vrijednosti, da bi tek na zadnjem ročištu smanjio tužbeni zahtjev i postupak pretvorio u spor male vrijednosti, ovisno o ocjeni bi li mu više odgovarao postupak propisan za pravne lijekove u redovnom postupku ili u postupku u sporove male vrijednosti (464.). Pored toga, okolnost da je tužitelj bez ikakvih za sebe štetnih posljedica bio ovlašten isticati neprimjereno visoke zahtjeve, omogućavalo mu je da na izvjestan način jača svoj položaj pri pokušaju mirnog rješenja spora, između ostaloga sklapanjem nagodbe, da tuženika sili da pri planiranju svojih financija, a time i života i/ili poslovanja, imobilizira više sredstava kao pričuvu ako tužitelj ipak uspije sa svojim zahtjevom itd.

Ako bi se izloženo stajalište prihvaćeno u praksi prije Novele 19, arg. a cohaerentia, a completudine, per analogiam, uopćilo u smislu da bi pravo na naknadu troškova postupka u bilo kojem slučaju u kojemu bi ono ovisilo o uspjehu u parnici bilo uvjetovano visinom naknade i nagrade prema Odvjetničkoj tarifi, visinom sudskih pristojbi, visinom troškova dokazivanja itd., tada je i u slučajevima u kojemu je tužiteljev zahtjev bio djelomično odbijen, dakle, ne samo kod smanjenja tužbenog zahtjeva odnosno djelomičnog povlačenja tužbe, trebalo primijeniti isti kriterij. Tuženik je i u tim slučajevima trebao imati pravo na naknadu troškova postupka samo ako su oni ovisili o visini tužbenog zahtjeva. Ako oni nisu ovisili o visini tužbenog

37 Tako u osnovi i Vučković, „Troškovi parničnog postupka kod smanjenja tužbenog zahtjeva kritika stava Vrhovnog suda Republike Hrvatske", pod 3. 
zahtjeva, tuženik je tada morao naknaditi troškove postupka tužitelju koji je uspio s dijelom zahtjeva koji je opravdavao njegov zahtjev za naknadu tih troškova. Tako je, npr. tužitelju koji je izvorno postavio zahtjev za isplatu $100.000,00 \mathrm{kn}$, kojemu je taj zahtjev odbijen za iznos od 89.000,00 kn i kojemu je dosuđen iznos od 11.000,00 kn, trebalo priznati pravo na naknadu troškova odvjetničkog zastupanja jer je njegov uspjeh u parnici opravdavao te troškove, budući da bi oni bili isti kao i da je već u tužbi utužio $11.000,00 \mathrm{kn} \cdot{ }^{38}$

Problematizirano stajalište zauzeto u sudskoj praksi trebalo je, simetrije radi, primijeniti i ako je tužitelj uspio u sporu u većoj mjeri od tuženika. U tom slučaju tuženik nije trebao tužitelju naknaditi troškove postupka prema kriteriju uspjeha u sporu, dakle razmjerno tom uspjehu (154/2.), ako bi oni bili isti neovisno o tom uspjehu.

Stajalište Vrhovnog suda o kojemu je riječ trebalo je, dakle, ili generalizirati i učiniti ga općim primarnim kriterijem za odlučivanje o naknadi parničnih troškova u slučaju djelomičnog uspjeha u parnici, ili ga nije trebalo primjenjivati ni u slučaju smanjenja tužbenog zahtjeva. Kriteriji za koje se smatralo da su mjerodavni u slučaju smanjenja tužbenog zahtjeva trebali su biti mjerodavni i u slučaju djelomičnog povlačenja tužbe (158/1.1.), odnosno djelomičnog odbijanja tužbenog zahtjeva (154/2.); oni su trebali biti mjerodavni i u slučaju djelomičnog priznanja tužbenog zahtjeva (331.). Njih je, međutim, trebalo primjenjivati i u slučaju preinake tužbe povećanjem tužbenog zahtjeva.

Ono što je rečeno o smanjenju tužbenog zahtjeva ako je tuženik imao pravo tražiti naknadu troškova postupka kad bi tužitelj povukao tužbu (158/1.1.), na odgovarajući način trebalo je prema prijašnjem uređenju vrijediti i u slučaju u kojemu bi tužitelj koji bi povukao tužbu imao pravo tražiti naknadu tih troškova (158/1.2., v. infra ad 3.).

U praksi je, prema prije važećem uređenju, bilo izraženo i shvaćanje, s kojim se treba složiti, da kad tužitelj smanji tužbeni zahtjev, naknadu parničnih troškova koji se odnose na smanjeni dio zahtjeva, tuženik može zatražiti i prije donošenja odluke o glavnoj stvari, ali i zajedno sa zahtjevom za naknadu ostalih troškova obračunatih prema smanjenom tužbenom zahtjevu ${ }^{39}$ (v. infra ad 5.).

38 Usp. tar. Br. 7. Tarife o nagradama i naknadi troškova za rad odvjetnika, Narodne novine, br. $148 / 09$.

39 VSRH: Rev-402/04 - INF-N5533/07. U konkretnom slučaju Vrhovni sud i drugostupanjski sud bili su zauzeli različita stajališta o tome do kada stranka mora staviti zahtjev za naknadu troškova nakon smanjenja tužbenog zahtjeva koji se tiču razlike između izvornog i smanjenog zahtjeva. Vrhovni je sud, pošavši od toga da je smanjenje tužbenog zahtjeva u biti povlačenje tužbe, ali djelomično povlačenje tužbe koje nema za posljedicu okončanje postupka pred prvostupanjskim sudom, već se procesne aktivnosti stranaka nastavljaju tako da u trenutku smanjenja tužbenog zahtjeva ukupni troškovi i konačni uspjeh stranaka u sporu još nisu poznati, zauzeo stajalište da o naknadi troškova koji se odnose na smanjeni dio tužbenog zahtjeva sud treba odlučiti u odluci o glavnoj stvari, a naknadu tih troškova tuženik može ostvarivati zajedno s naknadom ostalih troškova obračunatih prema smanjenom tužbenog zahtjevu. Drugostupanjski sud je, međutim, bio mišljenja da tuženiku ne pripada pravo na naknadu troškova koji se odnose na smanjeni dio prvobitno postavljenoga tužbenog zahtjeva zato što se, u smislu odredbe članka 164. stavka 7. ZPP-a, u slučaju povlačenja tužbe zahtjev za naknadu troškova može staviti na raspravu na kojoj 


\subsubsection{Uređenje nakon Novele 19}

\subsection{Postavljanje problema}

O tome kako bi se trebalo postaviti prema supra ad 2.3.3.1. izloženom stajalištu sudske prakse, formiranom prema uređenju troškovnog prava koje je važilo prije Novele 19, u kontekstu uređenja toga prava nakon te novele mogla bi se zastupati (barem) dva shvaćanja. Prema jednom od njih, ono bi dobilo svoju potvrdu novim uređenjem, po drugome, njegovoj primjeni ne bi bilo mjesta - jednako kao ni prema prijašnjem uređenju. Naime, za svako bi se od tih shvaćanja mogli pronaći argumenti u sustavu noveliranoga uređenja troškovnog prava - u osnovi polazeći od izmijenjenih odredaba stavka 2. članka 154. ZPP 19, koji glasi:

Ako su stranke djelomično uspjele u parnici, sud će najprije utvrditi postotak u kojemu je svaka od njih uspjela, zatim će od postotka one stranke koja je u većoj mjeri uspjela oduzeti postotak one stranke koja je u manjoj mjeri uspjela, nakon toga će utvrditi iznos pojedinih i iznos ukupnih troškova stranke koja je u većoj mjeri uspjela u parnici koji su bili potrebni za svrhovito vođenje postupka te će toj stranci odmjeriti naknadu dijela takvih ukupnih troškova koji odgovara postotku koji je preostao nakon navedenog obračuna postotaka u kojima su stranke uspjele u parnici. Pritom se omjer uspjeha u parnici ocjenjuje prema konačno postavljenom tužbenom zahtjevu, vodeći računa i o uspjehu dokazivanja u pogledu osnove zahtjeva.

\subsection{Shvaćanje prema kojemu odredbe stavka 2. članka 154. ZPP 19 treba doslovno tumačiti}

Prema prvom od nagoviještenih mogućih shvaćanja o supra ad 2.3.3.1. izloženom stajalištu sudske prakse, odredbe stavka 2. članka 154. ZPP 19 trebalo bi doslovno protumačiti - na takav bi zaključak upućivala eksplicitnost odredbe reč. 2. stavka 2. članka 154. ZPP 19. To bi značilo da bi tužbeni zahtjev istaknut $\mathrm{u}$ tužbi i naknadne promjene u pogledu njegova identiteta i visine bile irelevantne ako bi se razlikovale od konačno postavljenog zahtjeva. U kontekstu toga shvaćanja problematizirano stajalište sudske prakse ne samo da bi dobilo svoju potvrdu, već bi obesnažilo i relevantnost judikature formirane prema prijašnjem uređenju, $i$ to ne samo u slučaju smanjenja tužbenog zahtjeva, već i kod djelomičnog povlačenja tužbe i djelomičnog odricanja od tužbenog zahtjeva, ali i kod sukcesivnog povećanja ili preinake tužbenog zahtjeva.

Takvom bi se shvaćanju najprije moglo prigovoriti da bi ono bilo protivno temeljnom načelu parničnog troškovnog prava koje kao osnovicu za obračunavanje izdataka za poduzimanje pojedinih radnji uzima u obzir vrijednost predmeta spora $\mathrm{u}$ vrijeme njihova poduzimanja, načelu koje u pravilu vrijedi za obračun sudskih pristojbi, ${ }^{40}$ za izračunavanje visine nagrade koju je stranka dužna platiti odvjetniku kao

je tužba povučena, dok je u konkretnom slučaju tuženik stavio zahtjev za naknadu cjelokupnih troškova postupka na ročištu na kojem je glavna rasprava zaključena.

40 Prema članku 4. ZSP-a, obveza plaćanja pristojbe, ako tim zakonom nije drukčije propisano, nastaje: 1 . za podneske (tužbe, pravne lijekove, prijedloge za ovrhu i dr.), u trenutku kada se 
svom zastupniku ${ }^{41}$ itd. Ako bi se prihvatilo navedeno tumačenje odredbe reč. 2. stavka 2. članka 154. ZPP 19, tuženik koji bi svom odvjetniku plaćao nagradu za zastupanje prema vrijednosti predmeta spora u vrijeme poduzimanje pojedinih radnji i koji bi pretežno uspio u sporu, mogao bi od tužitelja koji bi na posljednjem ročištu bitno smanjio svoj zahtjev, tražiti naknadu tih troškova obračunatih samo prema vrijednosti predmeta spora tog smanjenog zahtjeva. Posljedice primjene toga tumačenja bile bi očito nepoštene i nepravične. One bi omogućavale i ozbiljne zloupotrebe prava u postupku (9., 10.) itd.

Protiv doslovnog tumačenja reč. 2. stavka 2. članka 154. ZPP 19 govorila bi i okolnost da se i nakon Novele 19 mogu tijekom postupka donositi posebne parcijalne odluke o konačnom snošenju troškova postupka, dakle neovisno o konačno postavljenom tužbenom zahtjevu - u postupovnim situacijama u kojima se ne zna kakav će biti konačno postavljeni zahtjev i kako će se spor uopće okončati. Naime, prema odredbi članka 165. ZPP-a u međupresudi ili djelomičnoj presudi sud može izreći da se odluka o troškovima postupka ostavlja za kasniju presudu, osim ako se kod djelomične presude ne radi o odluci kojom se postupak završava za nekog od suparničara. U tom je slučaju sud dužan odlučiti i o zahtjevu za naknadu troškova stranaka između kojih se tom odlukom postupak pred tim sudom završava (164/5., 165). Iz navedene odredbe, koja nije mijenjana Novelom 19, proizlazilo bi, a contrario, da bi sud bio ovlašten u međupresudi i djelomičnoj presudi odlučiti o troškovima postupka koji bi se ticali pitanja koja bi bila riješena tim presudama. To znači da bi u međupresudi sud mogao odlučiti o troškovima dokazivanja o kojemu je ovisila odluka o osnovi zahtjeva, na što bi upućivao i drugi dio reč. 2. stavka 2. članka 154. ZPP 19. Prema njemu pri ocjenjivanju omjera uspjeha u parnici treba voditi računa $i$ o uspjehu dokazivanja u pogledu osnove zahtjeva. Kad je riječ o djelomičnoj presudi, izvan slučaja u kojemu je sud dužan donijeti konačnu parcijalnu odluku (164/5., 165.), sud je ovlašten, ali ne i dužan, u toj presudi odlučiti i o troškovima postupka koji se tiču onoga o čemu njome odlučuje. Ti bi se troškovi mogli odnositi na dokaze izvedene radi utvrđenja činjenica o kojima bi ovisilo donošenje te presude, ali bi to mogli biti i troškovi drugih radnji koje bi bile poduzete u vezi s utvrđivanjem posebnih premisa za njezino donošenje. Pritom bi kao vrijednost predmeta spora trebalo uzeti ono o čemu se odlučivalo u incidentalnom postupku u kojemu bi ona bila donesena. $U$ tom bi slučaju došlo do svojevrsnoga razdvajanja postupaka (278., 313/3.), ${ }^{42}$ nakon čega bi svaki od tih materijalno razdvojenih postupaka imao svoju samostalnu sudbinu u utvrđivanju vrijednosti predmeta spora i time osnove za odlučivanje o troškovima postupka. Moglo bi se zaključiti da se tijekom postupka i nakon Novele 19 mogu donositi posebne odluke o troškovima postupka za čiji je obračun mjerodavna

predaju, a za podneske dane na zapisnik - kada je zapisnik dovršen, 2. za odgovor na tužbu po pravomoćnom završetku postupka za svaku stranku razmjerno uspjehu u parnici itd.

41 Arg. iz tar. br. 7. i 9. Odvjetničke tarife.

42 Prema odredbi članka 313. stavka 3. ZPP-a, sud može odrediti da se odvojeno raspravlja o pojedinim zahtjevima $u$ istoj tužbi i nakon završetka odvojenog raspravljanja može donijeti posebne odluke o njima. Djelomičnom presudom sud može odlučiti o jednom od više istaknutih zahtjeva, ali i o dijelu jednog kvalitativno djeljivog zahtjeva i o zahtjevu ili dijelu zahtjeva koji je istaknuo ili koji je istaknut prema nekom od suparničara (329.). 
vrijednost predmeta spora u vrijeme njihova donošenja, dakle ne ona koja bi se utvrđivala prema konačnom postavljenom zahtjevu.

Protiv doslovnoga tumačenja reč. 2. stavka 2. članka 154. ZPP 19 moglo bi se pozvati i na odredbe članka 156. ZPP-a o naknadi troškova po načelu krivnje i slučaja koji se dogodio stranci. Naime, prema tim odredbama sud može donositi posebne odluke o troškovima postupka na temelju navedenih kriterija uzimajući u obzir vrijednost predmeta spora u vrijeme njihova donošenja, dakle ne vrijednost koja bi se utvrđivala prema konačno postavljenom zahtjevu. Iako bi se u vezi s pozivanjem na te odredbe moglo prigovoriti da se one ne tiču slučajeva na koje se odnose odredbe stavka 2. članka 154. ZPP 19 o konačnom snošenju troškova postupka, već da za njih vrijedi odredba članka 164. stavka 7. ZPP-a, prema kojoj će sud tijekom postupka posebnim rješenjem odlučiti o naknadi troškova samo kad pravo na naknadu troškova ne ovisi o odluci o glavnoj stvari, to pozivanje ipak ima smisla utoliko što se pri donošenju odluke o naknadi troškova po načelu krivnje i slučaja koji se dogodio stranci uzima $\mathrm{u}$ obzir vrijednost predmeta spora u vrijeme donošenja te odluke, a ne vrijednost predmeta spora utvrđena prema konačno postavljenom zahtjevu. Te odredbe zajedno s drugim navedenim iznimkama od pravila indiciraju, zapravo potvrđuju stajalište da za obračun troškova nije relevantan samo konačno postavljeni zahtjev, već i zahtjev u sadržaju i kvantiteti kakav je bio u vrijeme njihova nastanka.

U vezi s ovdje razmatranim shvaćanjem moglo bi se primijetiti da se ni prema reč. 2. stavka 2. članka 154. ZPP 19 omjer uspjeha u parnici ne ocjenjuje isključivo prema konačno postavljenom tužbenom zahtjevu. Pri formiranju te ocjene treba voditi „računa i o uspjehu dokazivanja u pogledu osnove tog zahtjeva”, dakle odvojeno obračunati troškove koji se tiču utvrđivanja osnove zahtjeva, postupiti zapravo kao da je donesena međupresuda (165., v. supra), a onda tako odvojeno utvrđene troškove uzeti u obzir pri konačnom obračunu svih troškova. Naime, ako se troškovi dokazivanja u pogledu osnove zahtjeva ${ }^{43}$ trebaju uzeti u obzir kao posebna kategorija troškova, tada bi i o troškovima koji bi se ticali smanjenog dijela zahtjeva trebalo posebno voditi računa. Upravo bi odredba prema kojoj konačno postavljeni zahtjev nije jedina osnova za konačni obračun uspjeha u parnici govorila, arg. fortiori, per analogiam, u prilog stajalištu da bi u slučaju smanjenja tužbenog zahtjeva za utvrđivanje troškova koji bi se ticali smanjenog dijela tužbenog zahtjeva bio mjerodavan taj dio, da bi taj dio zahtjeva bio „konačno postavljeni zahtjev“"s obzirom na koji bi trebalo obaviti obračun troškova koji su nastali u povodu njega.

\subsection{Shvaćanje po kojemu odredbe stavka 2. članka 154. ZPP 19 ne treba doslovno tumačiti}

Prema drugom nagoviještenom shvaćanju (v. supra ad 2.3.3.3.1.), supra ad 2.3.3.1. izloženo stajalište sudske prakse, formirano prema uređenju troškovnog prava koje je važilo prije Novele 19, u kontekstu uređenja toga prava nakon nje ne bi više bilo relevantno.

43 To ne bi bili samo troškovi izravno vezani za izvođenje pojedinih dokaza, npr. troškovi vještaka, svjedoka itd., već i troškovi stranaka koje bi one imale u vezi s izvođenjem dokaza koji bi se ticali utvrđivanja osnove zahtjeva, uključujući i troškove njihova zastupanja. 
Ako bi se odredba reč. 1. stavka 2. članka 154. ZPP 19 uzela u obzir odvojeno od odredbe druge rečenice toga stavka, u slučaju smanjenja tužbenog zahtjeva obračun uspjeha u pogledu smanjenog dijela zahtjeva obavljao bi se prema kriterijima koje ona utvrđuje. Budući da ta odredba ne sadrži kriterije za utvrđivanje visine pojedinih troškova, već za utvrđivanje omjera uspjeha i za izračun njihovog konačnog iznosa koji će stranka koja je uspjela u manjoj mjeri biti dužna naknaditi protivnoj stranci koja je uspjela u većoj mjeri, prema njoj bi, kad bi bila uzeta, treba iznova naglasiti, odvojeno od reč. 2. stavka 2. članka 154. ZPP 19, u slučaju djelomičnog povlačenja tužbe trebalo utvrditi omjer uspjeha stranaka u pogledu smanjenog dijela tužbenog zahtjeva, a onda utvrditi u kojem bi omjeru stranka koja je uspjela u manjoj mjeri bila dužna naknaditi troškove koja je u vezi sa smanjenim dijelom zahtjeva imala stranka koja je uspjela u većoj mjeri. Pritom bi pri izračunavanju troškova u vezi sa smanjenim dijelom tužbenog zahtjeva, trebalo postupiti kao da je to bio poseban zahtjev istaknut u razdvojenoj parnici. Takvo bi tumačenje uvažavalo okolnost da se tijekom postupka identitet i veličina tužbenog zahtjeva mogu mijenjati i da bi stranke trebale imati pravo na naknadu troškova koji bi im nastali u dionicama postupka u kojima bi identitet i/ili veličina zahtjeva bili različiti.

Izloženo shvaćanje o značenju i primjeni odredbe reč. 1. stavka 2. noveliranoga članka 154. ZPP 19 utjecalo bi i na određenje značenja i primjenu odredbe reč. 2. stavka 2. članka 154. ZPP 19. kad bi se te odredbe nastojale dovesti u međusobnu vezu. Naime, odredbu prema kojoj se pri obračunu troškova postupka u slučaju djelomičnog uspjeha u parnici omjer uspjeha u parnici ocjenjuje prema konačno postavljenom zahtjevu, trebalo bi shvatiti u smislu da bi se u slučaju u kojemu bi tijekom postupka došlo (ili sukcesivno dolazilo) do smanjenja tužbenog zahtjeva, obračun za radnje poduzete prije smanjenja obavljao uzimajući kao osnovicu za taj obračun smanjeni dio zahtjeva, a za konačno postavljeni zahtjev taj zahtjev. Tako bi tuženik, u pravilu, u slučaju smanjenja tužbenog zahtjeva imao pravo tražiti naknadu svih svojih (potrebnih) troškova nastalih u vezi sa smanjenim dijelom zahtjeva kao da su oni nastali u posebnoj parnici u kojoj bi se vrijednost predmeta spora određivala prema tom dijelu zahtjeva, i to zato jer bi se uzelo da je u cijelosti uspio u toj ,posebnoj parnici“" u kojoj je tužitelj povukao tužbu.

Takvo tumačenje odredaba stavka 2. članka 154. ZPP 19 bilo bi u skladu, kako je to već rečeno supra ad 2.3.3.3.2., i s odredbom članka 165. ZPP-a prema kojoj sud može u međupresudi ili djelomičnoj presudi izreći da se odluka o troškovima postupka ostavlja za kasniju presudu, odredbe iz koje bi, a contrario, proizlazilo i da bi sud mogao u tim presudama odlučiti i o troškovima postupka. Naime, ako sud može definitivno odlučiti o troškovima postupka nastalim u povodu zahtjeva ili dijela zahtjeva o kojemu je odlučeno djelomičnom presudom vodeći računa o vrijednosti predmeta spora o kojemu je njome djelomično odlučeno, tada bi, per analogiam, arg. a cohaerentia, prema istim kriterijima (doduše u konačnoj odluci) trebalo odlučiti i u slučaju smanjenja tužbenog zahtjeva, dakle u slučaju djelomičnog povlačenja tužbe. To osobito stoga što sud djelomičnu presudu može donijeti i u slučaju djelomičnog odricanja od tužbenog zahtjeva (329/2.), radnje koja ima značenje jednoga kvalificiranog povlačenja tužbe. 
U prilog tom drugom shvaćanju govorili bi i drugi argumenti istaknuti supra ad 2.3.3.3.2. i 2.3.3.3.3.

\subsection{Supsidijarno suparničarstvo i supsidijarna objektivna kumulacija}

Ako u slučaju supsidijarnoga suparničarstva (197.) 4u $^{44}$ tužbeni zahtjev bude pravomoćno prihvaćen u odnosu na onoga od njih koji je primarno tužen, supsidijarni tuženik ima pravo na naknadu parničnih troškova, iako u odnosu na njega sud ne donosi odluku o glavnoj stvari. Prema judikaturi, treba smatrati da je parnica u koju se supsidijarni tuženik upustio za njega prestala teći i da tada treba primijeniti načela koja inače važe za povlačenje tužbe. ${ }^{45} \mathrm{U}$ vezi s navedenim stavom trebalo bi tek pojasniti da se kod supsidijarnog suparničarstva u slučaju ispunjenja rezolutivnoga uvjeta uz koji se tužba podnosi protiv supsidijarnog tuženika, dakle u slučaju prihvaćanja zahtjeva prema primarno tuženoj stranci, uzima kao da tužba u odnosu na supsidijarnoga tuženika nije ni bila podnesena. Zbog toga, ako se taj tužnik prije toga bio upustio u raspravljanje, nastupa pravna posljedica analogna pravnim posljedicama povlačenja tužbe, ${ }^{46}$ što opravdava i odgovarajuću primjenu odredbe članka 158. stavka 1. ZPP-a.

Tuženik bi imao pravo na naknadu troškova i u slučaju supsidijarne objektivne alternacije (188/2., 3.). Ako bi sud prihvatio primarno istaknuti zahtjev, trebalo bi smatrati kao da supsidijarno istaknuti zahtjev nije ni bio istaknut zbog čega bi u odnosu na njega nastala situacija analogna povlačenju tužbe. ${ }^{47}$

\section{NAKNADA TROŠKOVA KAD TUŽITELJ POVUČE TUŽBU ODMAH NAKON ŠTO TUŽENIK UDOVOLJI NJEGOVU ZAHTJEVU ILI IZ DRUGIH RAZLOGA KOJI SE MOGU PRIPISATI TUŽENIKU (158/2.)}

\subsection{Općenito}

Prema odredbi članka 158. stavka 2. ZPP 19, ako je tužba povučena ${ }^{48}$ odmah

44 Prema odredbi članka 197. ZPP-a, tužitelj može tužbom obuhvatiti dva ili više tuženika i tako što će tražiti da tužbeni zahtjev bude prihvaćen prema sljedećem tuženiku ako bude pravomoćno odbijen prema onome koji je u tužbi naveden prije njega, uz uvjet da prema svakom od njih ističe isti zahtjev ili da prema pojedinim od njih ističe različite zahtjeve koji su u međusobnoj vezi te uz uvjet da je isti sud stvarno i mjesno nadležan za svaki od zahtjeva.

O tzv. supsidijarnom suparničarstvu usp. Mihajlo Dika, Građansko parnično pravo, Stranke, njihovi zastupnici i treći u parničnom postupku, 4. knjiga. (Zagreb: Narodne novine, 2008.), § 19.

45 VSH: Gzz 7/89 - PSP 50/132.

46 Povučena tužba smatra se kao da nije ni bila podnesena i može se ponovo podnijeti (193/9.).

47 Tužitelj može dva i više tužbenih zahtjeva u međusobnoj vezi istaknuti u jednoj tužbi i tako da sud sljedeći od tih zahtjeva prihvati ako nađe da onaj koji je ispred njega istaknut nije osnovan (188/2.). Ti se zahtjevi mogu istaknuti u jednoj tužbi samo ako je sud stvarno nadležan za svaki od istaknutih zahtjeva i ako je za sve zahtjeve određena ista vrsta postupka (188/3.). O tom obliku alternacije tužbenih zahtjeva usp. Dika, GPP, VI., § 41.

48 O drugim razlozima zbog kojih tužitelj može povući tužbu, a koji se mogu pripisati tuženiku v. 
nakon što je tuženik udovoljio zahtjevu tužitelja ili iz drugih razloga koji se mogu pripisati tuženiku, troškove postupka dužan je tužitelju nadoknaditi tuženik. ${ }^{49}$ Ovom se odredbom odstupa od osnovnog pravila da je tužitelj koji je povukao tužbu dužan nadoknaditi troškove postupka tuženiku (v. supra ad 2.2.1.), pravila koje je inspirirano načelom presumiranog davanja povoda za parnicu. Tom se odredbom načelo dokazanog davanja povoda za parnicu uvodi kao iznimka od osnovnog pravila za utvrđivanje prava na naknadu troškova u slučaju povlačenja tužbe. Naime, tuženik je dužan tužitelju, koji je povukao tužbu i koji je dokazao da je tuženik dao povoda za parnicu, dokazavši da je to učinio jer je tuženik udovoljio njegovu zahtjevu nakon podnošenja tužbe ili zbog drugih razloga koji se mogu pripisati tuženiku, nadoknaditi troškove takve parnice.

Da bi tužitelj koji je povukao tužbu imao pravo na naknadu troškova postupka od tuženika, morale bi kumulativno biti ispunjene dvije pretpostavke (arg. ex 158/2.). Prva je pretpostavka da je tuženik, čija je obveza bila dospjela u vrijeme prije podnošenja tužbe, udovoljio zahtjevu tužitelja nakon podnošenja tužbe ${ }^{50}$ ili da su ispunjeni drugi razlozi koji se mogu pripisati tuženiku, i to do momenta do kojega tužitelj tijekom parnice može povući tužbu. Dakle u pravilu do zaključenja glavne rasprave u prvostupanjskom postupku (193/2.), odnosno, i nakon zaključenja glavne rasprave do pravomoćnosti odluke kojom se postupak pred sudom prvog stupnja dovršava (193/3.1.). ${ }^{51}$ Druga je pretpostavka da je tužitelj odmah nakon takvog udovoljenja njegovu zahtjevu odnosno nakon nastanka drugih razloga koji se mogu pripisati tuženiku, zapravo nakon momenta u kojemu je saznao ili bio dužan saznati za „udovoljenje” ili za druge razloge koji se mogu pripisati tuženiku ${ }^{52}$ - povukao tužbu. Pritom bi na tužitelju bio teret dokazivanja da su ispunjene obje navedene pretpostavke. On bi trebao dokazati da je tuženik svoju obvezu, koju je trebao ispuniti prije pokretanja parnice, ispunio nakon njezina pokretanja, odnosno da je za druge razloge koji se mogu pripisati tuženiku zbog kojih je to učinio saznao nakon podnošenja tužbe (v. infra ad 3.3.). Trebao bi dokazati i da je „odmah”, zapravo bez odgode, čim je saznao ili bio dužan saznati za navedene razloge zbog kojih je povukao tužbu i čim je to mogao učiniti, povukao tužbu (v. infra ad 3.4.).

Pretpostavke o kojima ovisi pravo tužitelja na naknadu troškova treba utvrditi

infra ad 3.2 .

49 Suđeno je da tužitelj koji povuče tužbu odmah nakon udovoljenja zahtjevu po tuženiku, ne samo da mu nije dužan nadoknaditi parnični trošak, već je ovlašten tražiti od tuženika naknadu svojih troškova - VSRH: Gzz-3/95 - INF 4710/99.

50 U tom je smislu suđeno ako je tuženik ispunio ugovornu obvezu prije podnošenja tužbe, tužitelj nema pravo na naknadu parničnog troška u smislu odredbe čl. 158. ZPP-a (ŽS ZG: Gžr-437/08 - INF-N 5707/08).

51 O povlačenju tužbe nakon zaključenja glavne rasprave usp. Dika, Građansko parnično pravo, Tužba, 6. knj., §§.

52 Prema pravnom stajalištu zauzetom na XXII. sastanku predstavnika vrhovnih sudova u bivšoj državi, tužitelj ima pravo na naknadu troškova učinjenih do ispunjavanja zahtjeva (ZSO, knj. XI. I XII., 1964., 153, cit. prema Poznić, Komentar Zakona o parničnom postupku, 342, koji opravdano primjećuje da bi relevantan trebao biti moment saznanja za ispunjenje, a ne sam moment ispunjenja. Bio bi zapravo odlučujući moment kad je tužitelj saznao ili trebao saznati za udovoljenje zahtjevu. 
na razini sigurnosti, ${ }^{53}$ i to stoga što je zahtjev za naknadu troškova svojevrstan materijalnopravni zahtjev o kojemu sud dužan odlučiti (arg. iz 221.a).

Ako bi tuženik ispunio ugovornu obvezu prije podnošenja tužbe, tužitelj ne bi imao pravo na nadoknadu parničnog troška u smislu odredbe čl. 158. stavka 2 ZPP $19,{ }^{54}$ i to stoga što tuženik u tom slučaju ne bi dao povoda za tužbu sa zahtjevom s kojim je podnesena. Tužitelj bi, eventualno, u posebnoj parnici, po općim pravilima, mogao tražiti naknadu štete koja bi se sastojala u troškovima pripremanja tužbe dok tuženik nije, prije njenog podnošenja, udovoljio zahtjevu.

\subsection{Moguće interpretacije odredbe članka 158. stavka 2. ZPP-a}

\subsubsection{Uvod}

Pravilo po kojem je, iznimno od općeg pravila (158/1., v. supra ad 2.3.1.), tuženik dužan tužitelju naknaditi troškove postupka ako je tužitelj povukao tužbu odmah nakon što je tuženik udovoljio njegovu zahtjevu ili zbog drugih razloga koji se mogu pripisati tuženiku (158/2.), ${ }^{55}$ moglo bi se tumačiti dvojako. U nastavku će dva nagoviještena interpretativna pristupa, najprije, biti razmotrena s aspekta slučaja u kojemu je do povlačenja tužbe došlo jer je tuženik udovoljio zahtjevu tužitelja, a zatim zbog drugih razloga zbog kojih je to učinjeno koji se mogu pripisati tuženiku.

\subsubsection{Povlačenje tužbe nakon udovoljenja zahtjevu tužitelja}

Prema prvom, restriktivnom tumačenju odredbe članka 158. stavka 2. ZPP 19 tuženik bi bio dužan naknaditi troškove tužitelju koji je povukao tužbu odmah nakon što je tuženik tijekom postupka udovoljio njegovu zahtjevu, bez obzira na razloge zbog kojih tuženik nije to prije toga učinio, ${ }^{56}$ odnosno neovisno o tome bi li tužitelj uopće uspio u sporu. ${ }^{57}$ Prema drugom tumačenju, tuženik bi bio dužan naknaditi troškove tužitelju koji je povukao tužbu odmah nakon što je tuženik udovoljio njegovu zahtjevu, samo ako je tuženik bio dužan udovoljiti zahtjevu tužitelja već u momentu podnošenja tužbe.

Prvo tumačenje, koje bi polazilo od doslovnoga značenja odredbe kojom je utvrđena iznimka od osnovnog pravila, koja ignorira moguće razloge zbog kojih je tuženik tek naknadno, tijekom postupka, udovoljio zahtjevu tužitelja i koje bi po svojoj logici bilo blisko latinskoj maksimi dura lex sed lex, moglo bi se objasniti (ali ne i opravdati) pragmatičnim razlozima - ono bi lišavalo sud potrebe da ispituje zašto je tuženik tek naknadno ispunio svoju obvezu, nudilo bi jednostavno i funkcionalno rješenje problema. Drugo tumačenje, za koje se čini da je u skladu s elementarnim zahtjevima pravičnosti i općim korektivnim pravilom da je onaj tko je svojom

53 Tako i Poznić, Komentar Zakona o parničnom postupku, 342 i Bazala, „Naknada razmjernog dijela parničnih troškova“, 34.

54 ŽS ZG: Gžr-437/08 - INF-N 5707/08.

55 O mogućim interpretacijama odredbe po kojoj je tuženik dužan naknaditi troškove postupka tužitelju koji je povukao tužbu zbog drugih razloga koji se mogu pripisati tuženiku v. infra.

56 Tako eksplicitno ŽS RI Gž-357/99 - IO-1/00-154.

57 ŽS RI: Gž-947/98 - ING PSP 2000-8-6. 
krivnjom ili slučajem koji mu se dogodio uzrokovao neke troškove postupka, dužan te troškove naknaditi protivniku neovisno o ishodu spora (156.), i koje je moguće, čak i bez nekih interpretativnih konstrukcija contra legem ili praeter legem, primijeniti i u razmatranom slučaju - pomiruje smisao odredbe stavka 2. članka 158. ZPP $19 \mathrm{~s}$ općim zasadama instituta naknade troškova postupka. Po prvom tumačenju tuženik koji bi naknadno tijekom postupka udovoljio zahtjevu tužitelja jer je njegova tražbina s obzirom na koju je on taj zahtjev istaknuo tek tada dospjela, morao bi tužitelju naknaditi sve troškove postupka kao da je tražbina tužitelja bila dospjela već u momentu podnošenja tužbe sudu. Po drugom tumačenju, tužitelj bi bio dužan tuženiku naknaditi troškove postupka koje mu je uzrokovao podnošenjem tužbe prije nego što je njegova utužena tražbina dospjela, dakle prije nego što ju je tuženik bio dužan ispuniti. U okviru ovoga drugog tumačenja tužitelj bi imao pravo na naknadu onih troškova postupka koji bi nastali nakon što je njegova tražbina koju je tuženik ispunio dospjela tijekom postupka, ako je odmah nakon što je tuženik to učinio, odnosno, pravilnije nakon što je za to saznao ili bio dužan saznati i to mogao učiniti, ${ }^{58}$ povukao tužbu i zatražio njihovu naknadu.

Suđeno je da ako je dug plaćen nakon podnošenja tužbe, a prije izdavanja platnog naloga, tužitelj dužan naknaditi troškove potrebne za prigovor da je dug plaćen ako je, s obzirom na okolnosti, imao dostatno vremena da prije prigovora povuče tužbu ili da zahtjev ograniči i da time otkloni potrebu pobijanja naloga. Ova je odluka zasnovana na shvaćanju da je prigovor neophodan jer pravomoćnošću naloga nastaje prekluzija u pogledu svih činjenica koje su do tog trenutka postojale, a nisu u parnici iznesene. Dužnik stoga ne bi mogao u ovršnom postupku koji bi bio pokrenut na temelju pravomoćnog platnog naloga iznijeti prigovor utemeljen na činjenici da je tražbina vjerovnika namirena isplatom prije nego što je nalog izdan. ${ }^{59}$

U praksi je zauzeto stajalište da tužitelj koji je povukao tužbu nakon što je tuženik udovoljio njegovu zahtjevu ima pravo tražiti naknadu troškova od tuženika bez obzira na okolnost što tuženiku ta tužba nije uopće ni dostavljena, dakle iako za nju nije ni saznao, ${ }^{60}$ odnosno stajalište da za primjenu odredbe reč. 2 . stavka 1. članka 158. ZPP 13 (158/2. ZPP 19) nije bitno je li parnica počela teći, već to da je tužba povučena odmah nakon što je tuženik učinio ono što je u tužbi zatraženo. ${ }^{61}$ Pritom bi, ipak, pravo tužitelja da u navedenim slučajevima traži naknadu troškova trebalo uvjetovati utvrđenjem da je tužitelj osnovano utužio svoju tražbinu prema tuženiku prije nego što ju je ovaj ispunio (v. supra ad 2.3.1.). ${ }^{62}$

58 U tom smislu i Poznić, Komentar Zakona o parničnom postupku, 343, pozivajući se na judikaturu.

59 VPSH: Sl-1265/72 od 16.11.1972, Pregl.-1973(3), br. 336. Usp. i Poznić, Komentar Zakona o parničnom postupku, 343.

60 ŽS ZG: Gž-1967/98 - ING PSP 1999-8-56.

61 ŽS ZG: Gž-6305/01 - ING PSP 2002-8-136.

62 Poznić, Komentar Zakona o parničnom postupku, 342, smatra da tuženik nije dužan tužitelju naknaditi troškove, da nije dao povoda tužbi, ako je bez odgode ispunio nedospjelu obvezu za koju je podnesena tužba. Isti autor, pozivajući se na stariju judikaturu, zastupa stajalište da tuženik koji se nije izjasnio o tužbenom zahtjevu, ali je tijekom spora tužitelju predao stvari zbog kojih je pokrenuta parnica, odgovara za parnične troškove. 


\subsubsection{Povlačenja tužbe zbog drugih razloga koji se mogu pripisati tuženiku}

Odredba stavka 2. članka 158. ZPP 19 izrijekom propisuje da je tuženik dužan naknaditi troškove postupka tužitelju koji je odmah povukao tužbu ne samo nakon što je tuženik udovoljio njegovu zahtjevu, kako je to bilo prije Novele 19, već i zbog drugih razloga koji se mogu pripisati tuženiku (158/2.). ${ }^{63}$ Drugi razlozi koji se mogu pripisati tuženiku redovito će se temeljiti na okolnostima koje će nastati nakon podnošenja tužbe sudu. U tom slučaju tužitelj bi trebao, da bi stekao pravo tražiti naknadu troškova od tuženika, povući tužbu odmah nakon što bi saznao ili bio dužan saznati za nastanak tih okolnosti i time za razlog koji se može pripisati tuženiku. $\mathrm{Ne}$ bi, dakle, u pravilu, bio relevantan moment kad su te okolnosti same po sebi nastale, već moment u kojemu je tužitelj za njih mogao, zapravo bio dužan saznati. Drugi razlozi koji se mogu pripisati tuženiku mogli bi, međutim, nastati i prije podnošenja tužbe, ali bi tužitelj trebao dokazati da je za njih opravdano saznao tek nakon toga. Koji bi moment konkretno bio relevantan za ocjenu pravodobnosti povlačenja tužbe - moment nastanka odnosnih okolnosti, moment saznanja za njihovo postojanje ili moment kad je tužitelj, uz primjenu dužne pažnje, za njih trebao saznati - prosuđivalo bi se prema prirodi tih okolnosti, ali i prema kriterijima materijalnog prava koji bi bili mjerodavni za kvalifikaciju odgovarajućega reagiranja tuženika s obzirom na pravnu prirodu njihova odnosa.

Drugi razlozi koji bi se mogli pripisati tuženiku zbog kojih bi tužitelj povukao tužbu mogli bi biti vrlo različiti. Tako bi tužitelju koji bi tužbom zatražio osudu tuženika na predaju određene stvari trebalo priznati pravo da od tuženika traži naknadu troškova postupka, ako bi povukao tužbu odmah nakon što bi saznao da je tuženik uništio utuženu stvar. Trebalo bi, naime, tužitelju priznati pravo da u tom slučaju ne iskoristi mogućnost da preinači tužbu zbog okolnosti koje su nastale nakon njezina podnošenja ili za koje je saznao nakon toga, iako su se dogodile prije toga (191/2.), da zahtjev za predaju stvari zamijeni zahtjevom za naknadu štete. ${ }^{64}$ Slično bi trebalo postupiti i kad bi tuženik nakon podnošenja tužbe otuđio stvar ili pravo o kome teče

63 Riječ je o razlozima zbog kojih je i prema uređenju prije te Novele, odgovarajućim tumačenjem prije važeće odredbe reč. 2. stavka 1. članka 158. ZPP 13, koja je izrijekom priznavala tužitelju pravo da traži naknadu troškova od tuženika samo ako bi tužitelj povukao tužbu odmah nakon što bi tuženik udovoljio njegovu zahtjevu. I prema prijašnjem je uređenju, naime, polazeći od tumačenja značenja navedene odredbe prema kojemu bi njome bila utvrđena tek jedna kazuistički određena iznimka, od odredbe koja je, arg. a cohaerentia, a completudine, per analogiam, indicirala postojanje općeg pravila o slučajevima u kojima je tužitelj koji bi povukao tužbu imao pravo tražiti naknadu troškova od tuženika, trebalo zastupati stajalište da je tužitelj imao to pravo uvijek onda kad bi do povlačenja tužbe došlo zbog razloga koji bi se mogli pripisati tuženiku, za koje bi on bio odgovoran. Drukčije, međutim, Poznić, Komentar Zakona o parničnom postupku, 342 i Betteto, Pravdni postopek, Zakon s komentarjem, 2. knj., 46. Za drukčije tumačenje opredijelila bi se i sudska praksa.

64 Razlozi zbog kojih tužitelj u navedenom slučaju ne bi htio preinačiti tužbu mogli bi biti različiti. On bi, npr. svoj zahtjev za naknadu štete mogao prebiti s nekim novčanim protupotraživanjem tuženika, mogao bi tu svoju tražbinu bez parnice naplatiti od treće osobe, npr. od osiguravajućeg društva, banke na osnovi bankarske garancije, od jamaca itd., mogao bi uskratiti predaju ili isporuku nekih stvari itd. 
parnica, ${ }^{65}$ svakako ako se prihvati, tzv. „teorija relevancije“666 itd.

\subsection{Značenje sintagme „tuženik udovoljio zahtjevu tužitelja” $и$ odredbi članka 158. stavka 2. ZPP 19}

Sintagmu ,tuženik udovoljio zahtjevu tužitelja" iz stavka 2. članka 158. ZPP 19 treba najprije shvatiti u njenom užem smislu, u smislu da se ona odnosi na slučaj u kojem je tuženik ispunio utuženu tražbinu tužitelja, tražbinu radi ostvarenja koje je on istaknuo kondemantorni tužbeni zahtjev. Izraz zahtjev u tom kontekstu ne bi značio tužbeni zahtjev on bi se tu koristio kao sinonim za građanskopravnu tražbinu. Tuženik može ispuniti samo tražbinu; on ne može ispuniti kondemantorni, konstitutivni ili deklaratorni tužbeni zahtjev. On te zahtjeve može samo priznati. Oni su upravljeni prema sudu od koga se traži pravnozaštitna radnja i sud ih može ,ispuniti" donoseći presudu kojom će ih prihvatiti.

Ipak, neovisno o prethodnoj izloženoj ,uskoj”, doslovnoj interpretaciji sintagme o kojoj je ovdje riječ, bilo bi moguće uzeti da bi tužitelj imao pravo na naknadu troškova i deklaratorne parnice u kojoj bi se tražilo utvrđenja nekog prava, npr. tražbine, ako bi tuženik to pravo priznao pravnom radnjom koja bi po svom učinku bila izjednačena s pravomoćnom presudom kojom bi deklaratorni zahtjev bio prihvaćen, npr. u obliku dispozitivne javnobilježničke isprave.

Slično bi vrijedilo i za konstitutivne parnice u kojima bi tuženik tijekom postupka poduzeo radnje kojima bi proizveo pravnu posljedicu zbog koje je konstitutivna parnica pokrenuta, odnosno kojima bi učinio suvišnima njezino daljnje vođenje, npr. ako bi tuženik tijekom parnice za otkaz nekog ugovora koji se bez njegove suglasnosti ne može izvansudski otkazati, dao izvan postupka tu suglasnost.

U praksi se prije Novele 19 u vezi sa značenjem sintagme ,tuženik udovoljio zahtjevu tužitelja“ u odredbi prije važećega članka 158. stavka 1. reč. 2. ZPP-a postavilo i pitanje može li se uzeti da je tuženik udovoljio zahtjevu tužitelja i kad je netko drugi to učinio umjesto njega. Suđeno je da bi navedena pretpostavka, okolnost da je zahtjevu tužitelja udovoljeno nakon podnošenja tužbe, bila ispunjena i kad bi to učinila treća osoba, npr. jedan od solidarnih sudužnika ${ }^{67}$ ili glavni dužnik kao osoba

65 Prema odredbi članka 195. ZPP, ako koja od stranaka otuđi stvar ili pravo o kojem teče parnica, to ne sprječava da se dovrši parnica među istim strankama.

66 Usp. Triva-Dika, Građansko parnično procesno pravo, 302 i 419. O teoriji relevancije usp. Dika, Građansko parnično pravo, Stranke, njihovi zastupnici i treći u parničnom postupku, 4. $k n j ., \S 12$.

67 VSRH: Rev-744/2010-2 - IO VSRH 1/2011-188., pozivajući se i na svoju odluku broj Rev100/00-2 od 23.9.2003. U konkretnom slučaju tužitelj je povukao tužbu odmah nakon što mu je glavni solidarni dužnik ispunio tražbinu u cijelosti. Pritom je Vrhovni sud zauzeo stajalište da se ispunjenje tražbine od drugoga solidarnog sudužnika ima smatrati jednako kao da ju je ispunio solidarno odgovorni tuženik, pronalazeći uporište za to stajalište u odredbi članka 414. ZOO 91 (43. ZOO 05), prema kojoj vjerovnik može zahtijevati od svakoga solidarnog dužnika ispunjenje obveze sve dok obveza ne bude potpuno ispunjena. 
koja za to ima pravni interes ${ }^{68}$ (arg. ex 161/2. ZOO 05). ${ }^{69} \mathrm{U}$ slovenskoj je judikaturi, međutim, na osnovi podudarnoga zakonodavnog uređenja, zauzeto stajalište da se u slučaju u kojem je tužitelj povukao tužbu zato što je tužbeni zahtjev ispunila jedna od solidarno obvezanih stranaka, dok su druge dvije (koje su obični suparničari) taj zahtjev osporile, ne može smatrati da ispunjenje od strane solidarnog obveznika ima isti učinak kao kad bi stranke same ispunile zahtjev kojemu prigovaraju. ${ }^{70}$

\subsection{Značenje riječi ,odmah” u odredbi članka 158. stavka 2. ZPP 19}

Nedefinirani pravni standard „odmah" u stavku 2. članka 158. ZPP 19 (v. supra ad 2.3.1.) treba shvatiti da bi tužitelj bio dužan povući tužbu čim bi saznao ili bio dužan saznati da je tuženik ispunio utuženu obvezu i bio u stanju to učiniti, dakle bez odgode, odugovlačenja. U praksi je zauzet stav da se smatra da je povlačenje uslijedilo odmah nakon udovoljenja zahtjevu ako je tužitelj povukao tužbu dvadesetog dana nakon što mu je tuženik isplatio iznos tražen tužbenim zahtjevom (tuženik je isplatio dugovanje iz prijepornog ugovora o zamjeni 5. veljače 1997., a tužitelj je povukao tužbu 26. veljače., pri čemu u međuvremenu nije održano ročište). ${ }^{71}$ Čini se da je taj stav in concreto bio motiviran okolnošću da se između momenta ispunjenja tražbine tužitelja i izjave tužitelja o povlačenju tužbe stranke, nisu poduzele druge radnje, zbog čega se moglo uzeti da je povlačenje uslijedilo izravno nakon ispunjenja.

Iz odredbe stavka 2. članka 158. ZPP 19 ne proizlazi sasvim jasno kakve bi bile pravne posljedice ako tužitelj ne bi odmah povukao tužbu. Čini se da se taj problem nije posebno javljao u praksi. Po jednom od mogućih rješenja, tužitelj koji ne bi odmah povukao tužbu, gubio bi pravo tražiti naknadu troškova od tuženika. Po drugom on to pravo ne bi gubio, ali bi bio dužan tuženiku naknaditi troškove koje bi on imao sudjelujući u parnici nakon što je tužitelj trebao povući tužbu. Treba uzeti da bi prvo rješenje, koje bi, uvodeći prekluziju zbog propuštanja da se tužba odmah

68 VSRH: Revx-794/2012-2 - IO VSRH 2/2014-182. U konkretnom je slučaju tužbenom zahtjevu umjesto tuženika udovoljio glavni dužnik. U tom je predmetu drugostupanjski sud bio odbio zahtjev tužitelja za naknadu troškova postupka zato što zahtjevu nije udovoljio tuženik već glavni dužnik. U reviziji protiv te odluke tužitelj je, pozivajući se na odgovarajuću judikaturu (odluke VSRH: Rev-1013/2004-2 od 7.3.206, Rev-2263/1998-2 od 5.12.2001; odluka ŽS PU: Gž-1683/2009-2 od 8. lipnja 2009.) i na odredbu članka 296. stavka 1. ZOO 91, ustvrdio da je za ostvarenje njegova prava da traži naknadu troškova postupka dovoljno da obvezu ispuni i svaka treća osoba koja za to ima pravni interes. Prema mišljenju Vrhovnog suda, koji je prihvatio reviziju i preinačio odluku drugostupanjskog suda, za primjenu odredbe članka 158. stavka 1. reč. 2. ZPP 13 bilo je dostatno da tražbinu ispuni tuženik ili treća osoba koja za to ima pravni interes, jer je tužitelj kao vjerovnik dužan primiti i ispunjenje od te osobe.

69 ZOO: Zakon o obveznim odnosima, Narodne novine, br. 35/05, 41/08, 125/11, 78/15.

70 Rješenje VSSL II Ips 399/2004 od 27.10.2005. Cit. prema Betteto, Pravdni postopek, Zakon s komentarjem, 2. knj., 46-47. Prema istom autoru, u jednom drugom predmetu (II Ips 274/2002) VSSL je svoju odluku da je tužitelj ovlašten tražiti naknadu parničnih troškova, koje mu mora platiti tuženik, utemeljio na argumentaciji da osiguravatelj, koji je u parnici imao položaj običnog umješača, sklapanjem izvansudske nagodbe i isplatom naknade štete, postupao u ime (jedinog) tuženika jer je naknadu štete isplaćena za tuženika, treba smatrati da ju je isplatila sama stranka.

71 VSH: Rev-644/98 - INF-N 4866/00. 
povuče i time pridonoseći procesnoj disciplini, ekonomičnosti postupka pa i pravnoj sigurnosti tuženika, odgovaralo okolnosti da je promptno povlačenje tužbe uvjet za primjenu iznimke od pravila. Drugo moguće rješenje bilo bi u skladu s osnovnim načelom da je troškove postupka dužna protivniku naknaditi ona stranka koja je dala povod za njihov nastanak. Ako bi se prihvatilo drugo navedeno rješenje, tužitelju bi trebalo priznati pravo na naknadu troškova nastalih do momenta do kojega je bez odgode mogao povući tužbu. Troškove nastale nakon tog momenta trebao bi u načelu on snositi zato što bi, propustivši da promptno povuče tužbu, dao povod za nastavak postupka koji bi se trebao nepovoljno okončati po njega. ${ }^{72}$

Ono što je rečeno u vezi s promptnim povlačenjem tužbe u slučaju naknadnog udovoljenja zahtjevu tužitelja vrijedilo bi u pogledu značenja riječi „odmah“ u odredbi članka 158. stavka 2. ZPP 19 i ako bi tužitelj povukao tužbu iz drugih razloga koji se mogu pripisati tuženiku.

\subsection{Djelomično povlačenje tuz̆be}

$\mathrm{O}$ djelomičnom bi se povlačenju tužbe moglo govoriti u subjektivnom i objektivnom smislu.

U slučaju formalnog suparničarstva (196/1.2.), ${ }^{73}$ tužbu bi mogao povući pojedini od više takvih aktivnih suparničara, kao što bi se tužba mogla povući i prema pojedinim od takvih pasivnih suparničara. Aktivni formalni suparničar koji bi povukao tužbu bio bi ovlašten tražiti naknadu troškova postupka od onog od takvih pasivnih suparničara u odnosu prema kojemu bi tužbu povukao - uz ispunjenje uvjeta iz odredbe članka 158. stavka 2. ZPP (v. supra ad 3.1.). Odgovarajuće bi vrijedilo i za aktivne, odnosno pasivne materijalne suparničare od kojih bi svaki isticao poseban zahtjev, odnosno prema kojima bi bili istaknuti posebni zahtjevi. U svim tim slučajevima, uz ispunjenje za to propisanih uvjeta (158/2.), tužitelj odnosno tužitelji mogao bi, odnosno mogli tražiti naknadu troškova od pojedinog tuženika ili, već prema slučaju, od svih njih.

U slučaju djelomičnog povlačenja tužbe, npr. zbog djelomičnog udovoljenja zahtjevu tužitelja, tužitelj bi mogao zatražiti naknadu troškova koji bi se ticali povučenog dijela zahtjeva (ili povučenog kojeg od više zahtjeva) ako bi tuženik za to dao povod. No, sud bi bio ovlašten u rješenju (kojim bi konstatirao povlačenje) izreći da će o njemu odlučiti u odluci koju će donijeti o preostalom dijelu tužbenog zahtjeva. ${ }^{74} \mathrm{U}$ tom bi slučaju trebalo na odgovarajući način primijeniti rješenja koja bi

72 Suđeno je da pravo tužitelja tražiti naknadu troškova nastaje samo ako je tužbu povukao odmah nakon ispunjenja zahtjeva. U protivnom odgovara za troškove koji su kao nepotrebni nastali za tuženika nakon ispunjenja zahtjeva, VPSH: Sl-612/64, odl. od 19.5.1964, Bilt. VPS 1964/2, S1-1231/71, odl. od 31. studenog 1971., Pregl. 1972(1). Cit. prema Poznić, Komentar Zakona o parničnom postupku, 343.

73 Formalnim suparničarima se smatraju suparničari u parnici u kojoj su predmet spora zahtjevi odnosno obveze iste vrste koje se temelje na bitno istovrsnoj činjeničnoj i pravnoj osnovi (196/1.2.). Usp. Dika, Građansko parnično pravo, Stranke, njihovi zastupnici $i$ treći u parničnom postupku, 4. knj., § 15/3.

74 ŽS RI: GŽ-2516/00 - IO 1/02-198. Poznić, Komentar Zakona o parničnom postupku, 342, pozivajući se na judikaturu, ističe da bi u povodu povlačenja samo nekih od više zahtjeva tuženik imao pravo na naknadu onih izdataka koji se tiču samo tih zahtjeva i srazmjerni dio 
bila prihvaćena u vezi sa smanjenjem tužbenog zahtjeva (v. supra ad 2.3.).

U slovenskoj doktrini je u vezi s djelomičnim povlačenjem tužbe izraženo mišljenje da bi u tom slučaju za odlučivanje o troškovima za povučeni dio zahtjeva bile mjerodavne odredbe čl. 158. SL ZPP ${ }^{75}$ dok bi se o naknadi troškova za preostali dio zahtjeva odlučivalo prema uspjehu. Prema tom mišljenju odredba 2. stavka članka 154. SL ZPP-a ne bi se isključivala s odredbom stavka 1. članka 158. SL ZPP, već bi se dopunjavale ako bi tuženik samo djelomično ispunio tužbeni zahtjev, a tužitelj bi se s time zadovoljio. Ako bi tužbu odmah nakon djelomičnog ispunjenja povukao, mogao bi zahtijevati od tuženika one troškove koji bi mu pripadali prema drugom stavku članka 154. SL ZPP. Budući da parnični troškovi nisu „pripadak“ samog zahtjeva, jer zahtjev za njihovo plaćanje nema nikakve veze s materijalnim ovlaštenjem s obzirom na koje tužitelj traži pravnu zaštitu, na pravilo iz stavka 1. članka 158. trebalo bi se pozvati i kada bi tužitelj smanjio tužbeni zahtjev na zahtjev za naknadu parničnih troškova. Odluka o troškovima ovisila bi o tome je li do povlačenja tužbe došlo zato što je tužitelj ispunio zahtjev ili iz drugih razloga. S obzirom na to da glavnog zahtjeva više nema, ne bi bilo moguće raspravljati o njegovoj osnovanosti kao o prethodnom pitanju da bi sud odlučio o troškovima postupka. ${ }^{76} \mathrm{~S}$ aspekta hrvatskoga prava moglo bi se primijetiti da bi sud bio dužan prejudicijalno riješiti pitanje osnovanosti zahtjeva i kad bi trebao odlučiti samo o zahtjevu za naknadu troškova, ako bi o rješenju tog pitanja ovisila njegova odluka o razlozima zbog kojih je tužba povučena, osobito o tome mogu li se oni pripisati tuženiku.

\subsection{Uskrata suglasnosti za povlačenje tužbe}

Sud odlučuje o troškovima postupka primjenom odredaba čl. 158. stavka 1. i 2. ZPP 19 samo ako je parnica završena povlačenjem tužbe, a ne i kad je zbog protivljenja tuženika odlučeno presudom. ${ }^{77}$ Tužitelj bi u slučaju u kojem bi do povlačenja tužbe moglo doći samo uz pristanak tuženika i u kojemu bi se tuženik koji je naknadno udovoljio zahtjevu odnosno koji bi se unatoč postojanju drugih razloga koji mu se mogu pripisati usprotivio povlačenju tužbe (193.), ${ }^{78}$ odgovarajući učinak

troškova koji se odnose na sve zahtjeve, pri čemu bi se taj razmjer utvrđivao prema vrijednosti navedenoj u tužbi za pojedine zahtjeve.

75 Doktrina na koju se ovdje upućuje odnosi se na slovenski Zakon o pravdnem postupku iz 1999. (SLZPP), čije su se odredbe čl. 154., 158. i 159., na koje se referira u ovom ogledu, numerički i sadržajno podudarale s odgovarajućim odredbama iz hrvatskoj ZPP 13.

76 Usp. Betteto, Pravdni postopek, Zakon s komentarjem, 2. knj., 47.

77 ŽS ZG: Gž-5763/07 23.10.2007. INF-N 5706/08. Tužitelj je u sporu radi iseljenja tuženika iz poslovnog prostora povukao tužbu, tuženik se usprotivio povlačenju pa je sud odbio tužbeni zahtjev. Tužitelj je ustvrdio da je tužbu povukao nakon što je tuženik ispraznio poslovni prostor. Prvostupanjski sud je priznao tužitelju troškove. Drugostupanjski sud je, međutim, zauzeo stajalište da u tom sporu nema mjesta primjeni čl. 158. st. 1. ZPP 13 jer spor nije okončan rješenjem kojim se utvrđuje da je tužba povučena, već da iz čl. 154. st. 1. ZPP proizlazi da tužitelj u opisanoj situaciji nema pravo na naknadu troškova. Konkretno, sud je o troškovima postupka odlučio primjenom načela presumiranoga povoda (154/1.), a ne na temelju dokazanog povoda (158/1.2.).

78 V. supra ad 2.2.2. 
trebao postići odricanjem od tužbenog zahtjeva. Naime, tuženiku treba priznati pravo da inzistira na meritornom okončanju spora ako bi tužbeni zahtjev postao neutemeljen jer je on naknadno ispunio svoju utuženu obvezu, odnosno zato što su nastupili drugi razlozi koji mu se mogu pripisati. Tužitelj koji bi htio okončati postupak i spriječiti donošenje kontradiktorne odluke koja bi bila nepovoljna po njega, trebao bi se odreći tužbenog zahtjeva. V. infra ad 4.

Suđeno je da za primjenu pravila o obvezi naknade troškova u povodu povlačenja tužbe nije važno to što je tuženik na povlačenje pristao nakon što mu se prethodno protivio. ${ }^{79}$

Tuženik bi imao pravo na naknadu troškova i kad bi se tek na raspravi suglasio s povlačenjem koje je izjavljeno poslije prigovora protiv platnog naloga (456/1) ${ }^{80}$

Imao bi pravo na naknadu troškova dolaska na ročište ako o povlačenju tužbe ne bi bio na vrijeme obaviješten. ${ }^{81}$

\subsection{Izvansudski sporazum o naknadi troškova u slučaju povlačenja tužbe}

U judikaturi i doktrini se postavilo pitanje mjerodavnosti izvansudskog sporazuma zaključenog tijekom parnice kojim tuženik oslobađa tužitelja od obveze naknade troškova postupka u slučaju povlačenja tužbe, odnosno kojim čak prihvaća obvezu da on naknadi troškove tužitelju. U jednom slučaju iz prakse u kojemu je tužitelj, koji je povukao tužbu, zatražio naknadu troškova postupka pozivajući se na izvansudski sporazum o tome, ti su mu troškovi dosuđeni. ${ }^{82} \mathrm{U}$ doktrini je, s jedne strane, u prilog takvog stajališta izneseno da bi, ako sud može uzeti u obzir i izvansudsku nagodbu koja je poslije pokretanja parnice zaključena o glavnom zahtjevu, razlozi svrsishodnosti nalagali da uzme u obzir i takav sporazum o troškovima postupka jer bi se i tu radilo o jednom materijalnom (subjektivnom) pravu. S druge strane, njegova je „slaba strana“ pronađena u tome što takav sporazum može pred sudom biti osporen, zbog čega bi sud njegovo postojanje trebao raščistiti, a to bi bilo protivno odredbi po kojoj sud odlučuje o naknadi troškova bez raspravljanja (164/1.). ${ }^{83}$

U slovenskoj je doktrini u vezi s mogućnošću da se odredbe članka 158. SL ZPP-a primijene i kad parnične stranke sklope izvansudsku nagodbu izraženo i mišljenje da ako se stranke o tome nisu dogovorile, odredba članka 159. stavka 1. SL ZPP-a o snošenju troškova u slučaju sudske nagodbe ne bi se mogla primijeniti, jer se ona odnosi na naknadu troškova u vezi sa sudskom, a ne i s izvansudskom nagodbom. Teža bi bila situacija u kojoj bi se stranke u izvansudskoj nagodbi, na temelju koje

79 VSV: Gž-133/1960, Glasnik 8/196. Cit. prema Poznić, Komentar Zakona o parničnom postupku, 342.

80 VPSH: S1.-819/67, odl. od 29.9.1967, PP 11/1967. Cit prema Poznić, Komentar Zakona o parničnom postupku, 341-342.

81 VPSSRB: Pž-1036/79 - Bilt. Br 4/1980, 14. Cit. prema Poznić, Komentar Zakona o parničnom postupku, 342.

82 VPS: Sl-957/57 od 19.4.1958, ev. cit. prema Poznić, Komentar Zakona o parničnom postupku, 342.

83 Usp. Poznić, Komentar Zakona o parničnom postupku 342, koji upućuje i na judikat kojim je zahtjev tužitelja odbijen s obrazloženjem da sud uzima ui obzir samo no što je sadržano u spisima parnice - VSH: Gž-3040/69, odl. od 29. srpnja 1970., Pregled 1970/II. 
bi došlo do povlačenja tužbe, glede naknade troškova sporazumjeli za primjenu drugih kriterija od onih iz članka 158. SL ZPP-a. Naime, u načelu su odredbe civilnog procesnog prava kogentne za sud i stranke, ali stranke ipak u vezi s nekim procesnim institutima imaju određenu autonomiju. Pored toga odredba čl. 158. SL ZPP ima materijalnopravni karakter, zbog čega bi prednost trebalo dati dispoziciji stranaka. ${ }^{84}$

\subsection{Isticanje prigovora kompenzacije}

Ako tužitelj povuče tužbu nakon što tuženik istakne prigovor prebijanja utužene tražbine s njegovom protutražbinom koja je dospjela prije pokretanja parnice, troškove je tuženiku dužan naknaditi tužitelj. ${ }^{85}$ Takav je tužitelj, koji je povlačenjem tužbe priznao da je protutražbina tuženika koju je ovaj prebio s njegovom utuženom tražbinom postojala i bila dospjela u vrijeme podnošenja tužbe, umjesto da sam istakne prigovor kompenzacije, dakle da izvansudskom dispozicijom izvrši prijeboj svoje dospjele tražbine s dospjelom protutražbinom tuženika, nepotrebno utužio svoju tražbinu. U tom bi slučaju zapravo bilo mjesta primjeni latinske maksime dolo facit qui petit quod redditurus est (Paulus - D.50, 17, 173, 3). ${ }^{86}$

Ako bi tužitelj povukao tužbu nakon što bi tuženik tijekom postupka istaknuo prigovor prijeboja utužene tražbine s njegovom protutražbinom koja je dospjela nakon utuženja, tužitelj bi u načelu imao pravo tražiti naknadu troškova od tuženika i to stoga što on u vrijeme utuženja nije mogao prebiti svoju dospjelu tražbinu s još nedospjelom protutražbinom tuženika. U tom bi slučaju tuženik koji bi bio u zakašnjenju dao povod za tužbu. ${ }^{87}$ Tužitelju bi se, međutim, moglo osporiti pravo da traži naknadu troškova za radnje poduzete nakon momenta nakon kojega je sam mogao isticanjem prigovora kompenzacije prebiti svoju utuženu tražbinu s protutražbinom tuženika i zatim povući tužbu. Svakako bi postupanje stranaka u kontekstu rješenja sudbine utužene tražbine kompenzacijom trebalo vrednovati i s aspekta zahtjeva da su stranke dužne savjesno se koristiti pravima koja su im priznata Zakonom (9.), odnosno da moraju nastojati da se postupak provede bez odugovlačenja, u razumnom roku i sa što manje troškova (10/1.).

Ako bi tužitelj u povodu prigovora prebijanja osporio tuženikovu tražbinu, bilo da je ono izneseno kao jedino sredstvo obrane, bilo kao eventualno uz druga, obveza

84 Usp. Betteto, Pravdni postopek, Zakon s komentarjem, 2. knj., 47, upozoravajući i na različitu praksu slovenskih sudova.

85 VPSSL: S1-394/72-3, odl. od 8.9.1972, Cit. prema Poznić, Komentar Zakona o parničnom postupku, 343-344.

86 Usp. Poznić, Komentar Zakona o parničnom postupku, 344.

87 Usp. Poznić, Komentar Zakona o parničnom postupku, 344, koji, ipak, pozivajući se na stariju judikaturu, primjećuje da bi tužitelj dao povod za parnicu u slučaju u kojemu bi vremenski razmak između dospjelosti njegove utužene tražbine i dospjelosti protutražbine tuženika bio kratak, npr. ako bi iznosio samo nekoliko dana, i ako zbog toga tužitelj ne bi pretrpio nikakvu štetu ako ne bi utužio svoju tražbinu prije dospjelosti protutražbine tuženika, već ako bi pričekao i njezino dospijeće i onda izjavio prijeboj, te da bi trebao snositi troškove postupka. Autor priznaje, međutim, da bi slaba strana ovog stajališta bila u tome što je kratkoća spomenutoga vremenskog razmaka neodređen pojam koji u praksi može dovesti od različitih shvaćanja. 
naknade parničnih troškova ovisila bi o uspjehu stranaka u parnici (154.). ${ }^{88}$

\section{ODRICANJE OD TUŽBENOG ZAHTJEVA}

Nakon Novele 19, nije samo tužitelj koji povuče tužbu, kako je to bilo doslovno prema uređenju prije te novele (158/1.1. ZPP 13), već je i tužitelj koji se odrekne tužbenog zahtjeva dužan u pravilu tuženiku naknaditi troškove postupka (158/1. ZPP 19). S tim da je tužitelj, ipak, iznimno od toga pravila, koji je ne samo povukao tužbu, kako je to izrijekom propisivala odredbe reč. 2. stavka 1. članka 158 ZPP 13, već i koji se odrekao tužbenog zahtjeva odmah nakon što je tuženik udovoljio zahtjevu tužitelja ili zbog drugih razloga koji se mogu pripisati tuženiku, ovlašten tražiti od tuženika da mu naknadi troškove postupka (158/2. ZPP 19). ${ }^{89}$ Navedenima proširenjem domašaja odredaba koje su prije Novele 19 izrijekom uređivale samo prava stranaka u slučaju povlačenja tužbe i na njihova prava u slučaju odricanja od tužbenog zahtjeva, eksplicitno je riješeno i pitanje primjenjivosti tih odredaba na odricanje od tužbenog zahtjeva, eksplicitno je prihvaćeno zakonsko rješenje do kojega se, arg. a minori ad maius, a fortiori, a cohaerentia, dolazilo i prema prijašnjem uređenju..$^{90}$ Odricanjem od tuženog zahtjeva tužitelj stvara uvjete za donošenje presude na temelju odricanja (331.a), presude kojom se spor ne rješava samo postupovnopravno kao u slučaju povlačenja tužbe, već i meritorno u korist tuženika. Naime, povlačenjem tužbe, parnica prestaje teći, ali tužitelj povučenu tužbu može ponovno podnijeti (193/9.). Nakon donošenja presude na temelju odricanja tužitelj ne smije ponovno podnijeti tužbu sa zahtjevom o kojemu je odlučeno tom presudom (333/2.; ne bis in idem).

Ako bi se tuženik koji se već upustio u raspravljanje o glavnoj stvari usprotivio povlačenju tužbe, svakako kad bi na to imao pravo (193/2.) (v. supra ad 2.2.), tužitelj bi se, da bi mogao tražiti naknadu troškova od tuženika koji je ispunio svoju obvezu prema njemu, morao odreći tužbenoga zahtjeva (331.a). Inzistiranje tuženika na nastavku postupka i donošenju meritorne odluke nakon što je ispunio svoju obvezu ne bi se moglo smatrati zloupotrebom procesnih ovlaštenja, nepotrebnim izazivanjem daljnjega postupka i stvaranjem suvišnih troškova. Štoviše, moglo bi se uzeti da bi tužitelj koji se ne bi odrekao tužbenoga zahtjeva, radnjom kojom bi se ne samo postupovnopravno već i meritorno okončao postupak, uzrokovao nastavak postupka i troškove koji bi time bili izazvani. ${ }^{11}$

Ako bi se, međutim, tužitelj odrekao tužbenog zahtjeva odmah nakon što bi tuženik udovoljio njegovu zahtjeva ili $\mathrm{i}$ iz drugih razloga koji se mogu pripisati tuženiku, tuženik bi se eventualno mogao usprotiviti zahtjevu tužitelja za naknadu troškova postupka koji bi u slučaju odricanja bili viši nego u slučaju povlačenja tužbe,

88 Usp. Poznić, Komentar Zakona o parničnom postupku, 344.

89 O doslovnom tekstu navedenih odredaba v. supra ad 1.

90 O tome da je prema judikaturi i prije Novele 19 odricanje od tužbenog zahtjeva dovodilo do istih pravnih posljedica kao i povlačenje tužbe usp. Ivo, Grbin, „Troškovi parničnog postupka”, Naša zakonitost br. 9-10 (1989.): 1069. Odricanje od tužbenoga zahtjeva tretiralo se kao kvalificirano povlačenje tužbe sve do Novele 1990. (arg. ex 193/4.-7. ZPP prije Novele iz 1990.).

91 U tom smislu i ŽS VŽ: Gž-2428/02 od 12. ožujka 2003. 
npr. usprotiviti se zahtjevu da nadoknadi pristojbe za presudu na temelju odricanja ili za naknadu mogućih povećanih troškova odvjetnika tužitelja koji bi umjesto čiste postupovne radnje povlačenja tužbe poduzeo meritornu radnju odricanja od tužbenog zahtjeva. ${ }^{92}$ Takvo bi stajalište bilo inspirirano odredbom prema kojoj sud, stranke i drugi sudionici moraju nastojati da se postupak provede bez odugovlačenja, u razumnom roku i sa što manje troškova (10/1.1.). Tom bi se stajalištu moglo suprotstaviti protuargumentacijom da tužitelj slobodno raspolaže svojim zahtjevom u granicama dopuštenog (3/1.-3.), da je odricanjem od tužbenog zahtjeva i stvaranjem uvjeta za donošenje presude na temelju odricanja (331.a) tuženiku omogućio ostvarivanje više razine pravne zaštite te da je takvo rješenje i u javnom interesu jer se definitivno otklanja mogućnost ponovnog utuženja (arg. ex 193/9).

\section{POSTAVLJANJE ZAHTJEVA ZA NAKNADU TROŠKOVA POSTUPKA}

Kad se tužba povuče na raspravi, stranka je dužna zahtjev za naknadu troškova staviti prije donošenja rješenja suda kojim će utvrditi da je došlo do povlačenja tužbe (arg. ex 164/3.). ${ }^{93} \mathrm{U}$ tom je smislu suđeno da je prvostupanjski sud ako tužiteljica nije postavila zahtjev za naknadu troškova prije donošenje rješenja o povlačenju protutužbe, odbivši u cijelosti njezin tužbeni zahtjev, pravilno osudio tužiteljicu da tuženiku naknadi u cijelosti parnični trošak. ${ }^{94}$

Tužitelj koji u podnesku povuče tužbu, trebao bi u tom podnesku postaviti zahtjev za naknadu troškova postupka (164/3.). ${ }^{95}$ Ako bi tužitelj u podnesku povukao tužbu, tuženik bi svoj zahtjev za naknadu troškova trebao podnijeti u roku u kojem bi se imao pravo izjasniti o povlačenju tužbe. ${ }^{96}$

U slučaju presumiranoga povlačenja tužbe, u nedostatku posebnog pravila o tome, trebalo bi postupiti analogno kao u slučaju u kojemu je tužitelj povukao tužbu izvan ročišta. S time da bi rok od petnaest dana za postavljanje zahtjeva počeo teći tek od dana kad bi strankama bilo dostavljeno rješenje suda kojim bi bilo utvrđeno da je tužba povučena (arg. ex 158/1., 164/8., 193/2., 3.). U tom je smislu suđeno da i kod presumiranoga povlačenja tužbe rok za podnošenje zahtjeva za naknadu troškova počinje teći nakon dostave tuženiku rješenja o povlačenju tužbe. ${ }^{97}$

92 Arg. iz tbr. 1. i 2. Tarife sudskih pristojbi uz ZSP (v. bilj. 33.).

93 VSH: Rev-1833/95 - IO 2/1998-99.

94 VSH: Rev-1833/95 - IO 2/1998-99, INF 4712-4713/99.

95 Prema odredbi članka 164. stavka 3. ZPP-a stranka je dužna zahtjev za naknadu troškova staviti najkasnije do završetka raspravljanja koje prethodi odlučivanju o troškovima. Ako je riječ o donošenju odluke bez prethodnog raspravljanja, stranka je dužna zahtjev za naknadu troškova staviti u prijedlog o kojem sud treba odlučiti.

96 Smatra se da je tuženik koji se u roku od 15 dana od dana obavijesti o povlačenju tužbe ne izjasni o tome pristao na povlačenje (193/2.). Ako je tužba uz izričiti pristanak tuženika povučena nakon zaključenja glavne rasprave do pravomoćnosti odluke kojom se postupak pred sudom prvog stupanja dovršava, tuženik svoj zahtjev za naknadu troškova postupka mora postaviti najkasnije u svojoj suglasnosti za povlačenje tužbe (193/3.).

97 ŽS ST: Gžmal-718/2010 - IO VSRH 2/2010-191. Prvostupanjski je sud, pozivajući se na odredbu članka 168. stavka 1. ZPP-a u vezi s odredbom 217. stavka 3. ZPP bio odbacio 
Prema sudskoj praksi, ako povlačenje tužbe nije obavljeno na raspravi, tuženik ima pravo postaviti zahtjev za naknadu parničnih troškova u roku od 15 dana od dostave rješenja o povlačenju tužbe, jer je tek tada primio obavijest o ispunjenju zakonskih pretpostavaka za presumirano povlačenje tužbe. ${ }^{98}$ Stoga ako je tužba povučena izvan rasprave, sud neće tuženiku dosuditi parnične troškove koje je on zatražio po proteku roka od petnaest dana od dana primitka obavijesti da je tužba povučena. ${ }^{99}$

\section{PRIMJENA DRUGIH POSEBNIH PRAVILA O NAKNADI TROŠKOVA POSTUPKA U SLUC̆AJEVIMA IZ ČLANKA 158. ZPP-A}

Suđeno je prema uređenju prije Novele 19 da ako tužitelj povuče tužbu, sud ne može odrediti da svaka stranka snosi svoje troškove, ${ }^{100}$ i to stoga što se prema odredbi članka 154. stavka 2. ZPP $13,{ }^{101}$ da bi se donijela takva odluka, pretpostavlja da su obje stranke postigle približno isti uspjeh. Ako je, međutim, jedna stranka postigla znatno veći uspjeh, tada se ne primjenjuje ta odredba, već odredba stavka 2. članka

kao nepravodoban zahtjev tuženika za naknadu troškova postupka, smatrajući da je kod presumiranog povlačenja tužbe rješenje koje sud donosi u povodu takvog povlačenja tužbe deklaratornog karaktera. Zbog toga je tuženik bio ovlašten zahtijevati od protivne stranke naknadu troškova u roku od 15 dana računajući od dana kada je po sili zakona došlo do takvog povlačenja tužbe. Prema stajalištu drugostupanjskog suda, koji je preinačio prvostupanjsku odluku, zakonsko uporište prema kojemu je u slučaju povlačenja tužbe (pa makar bilo ono i presumirano) protivna stranka ovlaštena od tužitelja zahtijevati naknadu troškova postupka čine odredbe članka 158. stavka i članka 164. stavka 8. ZPP, i to stoga što tuženik nije mogao niti trebao znati jesu li se u konkretnom slučaju ispunili zakonski uvjeti da bi ex lege došlo do presumiranog povlačenja tužbe, jer ispunjenje tih uvjeta ne ovisi samo o njemu, već i o protivnoj stranci.

98 VSRH: Revt-169/2011-2 - IO VSRH 2/2013-201. Prema stajalištu Vrhovnog suda odredbe članka 158. stavak 1. ZPP 13 (158/1., 2. ZPP 19) odnosile su se kako na izričito tako i na presumirano povlačenje tužbe te da je odredba članka 164. stavka 8. ZPP-a („U slučaju iz članka 158. /.../, ako povlačenje tužbe /.../ nije obavljeno na raspravi, zahtjev za naknadu troškova može se staviti u roku od 15 dana nakon dostave obavijesti ili odluke.“) ,posebna u odnosu na“ odredbu članka 164. stavka 3. ZPP („Zahtjev za naknadu troškova stranka je dužna staviti najkasnije do završetka raspravljanja koje prethodi odlučivanju o troškovima, a ako je riječ o donošenju odluke bez prethodnog raspravljanja, stranka je dužan zahtjev za naknadu troškova staviti u prijedlogu o kojemu sud treba da odluči."). Drugostupanjski je sud, naime, bio kao mjerodavnu primijenio odredbu članka 164. stavka 3. ZPP-a. U konkretnom slučaju obje stranke nisu pristupile na ročište i rasprava nije održana (295.). Prema stajalištu Vrhovnog suda, uvjeti za presumpciju o povlačenju tužbe nisu se ostvarili na ročištu, kako je mislio drugostupanjski sud, jer rasprave nije bilo. Zato je tuženik zahtjev za naknadu troškova trebao moći postaviti u roku od 15 dana od dana dostave rješenja o povlačenju tužbe, jer je tek tada obaviješten o ispunjenju pretpostavaka za presumirano povlačenje tužbe. U slučaju presumiranog povlačenja tužbe tuženiku pripada pravo staviti zahtjev za naknadu troškova u roku od 15 dana na temelju odredbe članka 164. stavka 8. ZPP-a.

99 VSRH: Rev-2442/98 od 17. srpnja 2001. 158, 164/7.

100 VSRH: Rev x -77/2008-2 (12.11.2008.) INF 5857 od 24. travnja 2010.

101 Prema toj odredbi, ako bi stranka djelomično uspjela u parnici, sud je mogao s obzirom na postignuti uspjeh, odrediti da svaka stranka snosi svoje troškove ili da jedna stranka naknadi drugoj i umješaču razmjeran dio troškova. 
154 ZPP 13, prema kojoj je jedna stranka dužna drugoj stranci nadoknaditi razmjerni dio troškova. Budući da je u konkretnom slučaju postupak završio povlačenjem tužbe, o troškovima je trebalo odlučiti primjenom odredaba članka 158. ZPP 13.

Navedeno stajalište zauzeto u sudskoj praksi vrijedilo bi u bitnome i nakon Novele 19. Naime, u noveliranom članku 154. ZPP 19 odredba stavka 2. članka 154. 13 nadomještena je (uz određene izmjene) odredbom stavka 4. članka 154. ZPP 19, prema kojoj ako „su stranke djelomično uspjele u parnici u približno jednakim dijelovima, sud može odrediti da svaka stranka snosi svoje troškove ili da jedna stranka naknadi drugoj stranci samo pojedine troškove primjenom članka 156. stavka 1. ovoga Zakona". Budući da i nova odredba stavka 4. članka 154. ZPP 19 mogućnost donošenja odluke po kojoj bi svaka stranka snosila svoje troškove uvjetuje donošenjem konačne odluke prema kojoj su stranke djelomično uspjele u približno jednakim dijelovima, ona se u pravilu ne bi mogla primijeniti na slučajeve u kojima je tužitelj povukao tužbu ili se odrekao tužbenog zahtjeva - za te bi slučajeve bile mjerodavne odredbe članka 158. stavka 1. i 2. ZPP 19. Ipak, iznimno, u slučaju u kojemu bi sud istom odlukom odlučio o troškovima postupka u povodu smanjenja (djelomičnog povlačenja) tužbenog zahtjeva i o troškovima postupka u povodu preostalog dijela zahtjeva, ako bi bili ispunjeni uvjeti iz stavka 4. članka 154. ZPP 19 mogla bi se na odgovarajući način primijeniti ta odredba, a ne odredbe članka 158 . stavaka 1. i 2. ZPP 19.

\section{ZAKLJUČNE NAPOMENE}

Noveliranim odredbama članka 158. stavka 1. i 2. ZPP 19 svakako je unaprijeđeno uređenje instituta naknade troškova u slučaju povlačenja tužbe odnosno odricanja od tužbenog zahtjeva u usporedbi s prije važećim uređenjem. Ipak, bit će potrebno u praksi stabilizirati stajališta o čitavom nizu spornih pitanja koja se mogu postaviti i u vezi s tim novim uređenjem. Autor ovog ogleda nastojao je upozoriti na neke od probleme koji se mogu javiti u vezi s tumačenjem i primjenom tog uređenja, ali i predložiti njihova moguće rješenja. Ne bi trebalo isključiti ni potrebu da se pri nekoj od narednih revizija ili reformi parnične procedure pokušaju otkloniti neke od interpretativnih nedoumica što ih izazivaju novelirane odredbe članka 158. stavka 1. i 2. ZPP 19, a na koje je upozoreno u ovom radu.

\section{LITERATURA}

Knjige i članci:

1. Bazala, Branko. „Naknada razmjernog dijela parničnih troškova“. Odvjetnik br. 1 (1958).

2. Betteto, Nina. Pravdni postopek, Zakon s komentarjem, 2. knj. Ljubljana: GV Založba, 2005.

3. Dika, Mihajlo. Građansko parnično pravo, Stranke, njihovi zastupnici i treći u parničnom postupku, 4. knj. Zagreb: Narodne novine, 2008.

4. Dika, Mihajlo. Građansko parnično pravo, Tužba, 6. knj. Zagreb: Narodne novine, 2009.

5. Dika, Mihajlo. „O troškovnom statusu umješača nakon Novele Zakona o parničnom postupku iz 2019.“. U: Zbornik radova s V. Međunarodnog savjetovanja - Aktualnosti građanskog procesnog prava - nacionalna i usporedna pravnoteorijska i praktična dostignuća, ur. Dinka Šago et al. Split: Pravni fakultet, 2019.: 1-38. 
6. Fashing, Hans W. Kommentar zu den Zivilprozessgesetzen. Wien: II.B., 1962.

7. Grbin, Ivo. „Troškovi parničnog postupka”. Naša zakonitost br. 9-10 (1989): 1066-1078.

8. Grbin, Ivo. „Vrijednost predmeta spora te troškovi parničnog postupka”. U: Godišnjak 14., Aktualnosti hrvatskog zakonodavstva i pravne prakse, Zagreb: Organizator, 2007.

9. Hrvatin, Branko. „Naknada troškova parničnog postupka“. Hrvatska gospodarska revija 47, br. 11 (1998): 35-40.

10. Poznić, Borivoje. Komentar Zakona o parničnom postupku. Beograd: Pravni fakultet, 2009.

11. Triva, Siniša i Mihajlo Dika. Građansko parnično procesno pravo. Zagreb: Narodne novine, 2004.

12. Vučković, Vladimir. „Troškovi parničnog postupka kod smanjenja tužbenog zahtjeva kritika stava Vrhovnog suda Republike Hrvatske". Hrvatska pravna revija br. 12 (2016): 76-78.

Pravni propisi:

1. Tarifa o nagradama i naknadi troškova za rad odvjetnika, Narodne novine, br. 91/04., 37/05., 59/07.

2. Tarifa o nagradama i naknadi troškova za rad odvjetnika, Narodne novine, br. 148/09.

3. Zakon o obveznim odnosima, Narodne novine, br. 35/05., 41/08., 125/11., 78/15.

4. Zakon o parničnom postupku, Narodne novine, br. 53/91., 91/92., 112/99., 88/01., 117/03., 88/05., 2/07., 84/08., 96/08., 123/08., 57/11., 148/11. - pročišćeni tekst, 25/13., 89/14. Odluka Ustavnog suda Republike Hrvatske, 70/19.

5. Zakon o sudskim pristojbama, Narodne novine, br. 74/95., 57/96., 137/02., (26/03.), 125/11., 112/12., 157/13., 110/15.

Sudska praksa:

1. OS DU: Gž-911/85 - PSP 31/89.

2. VPS: S1-957/57 od 19.4.1958.

3. VPSH: Sl-1265/72 od 16.11.1972, Pregl.-1973(3), br. 336.

4. VPSH: Sl-612/64, odl. od 19.5.1964., Bilt. VPS 1964/2, Sl-1231/71, odl. od 31.11.1971., Pregl. 1972(1)

5. VPSH: Sl-819/67, odl. od 29.9.1967., PP 11/1967.

6. VPSSL: Sl-394/72-3, odl. od 8.9.1972.

7. VPSSRB: Pž-1036/79 - Bilt. br 4/1980, 14.

8. VSH: Gzz 7/89 - PSP 50/132.

9. VSH: Gž-3040/69, odl. od 29.7.1970, Pregled 1970/II.

10. VSH: Rev-1833/95 - IO 2/1998-99, INF 4712-4713/99.

11. VSH: Rev-1833/95 - IO 2/1998-99.

12. VSH: Rev-644/98 - INF-N 4866/00.

13. VSH: Rev-644/98 - INF-N 4874/00.

14. VSRH 2/2011-200., pozivajući, uz ostalo, i na svoje odluke broj Revt-35/2004, Rev402/2004 i Rev-5231/2005.

15. VSRH, od 22. siječnja 2013. broj Revr-127/11-2. pozivajući se na odluku broj Revr1428/2009-2 od 27. listopada 2010.

16. VSRH, od 27.10.2010., broj Revr-1428/2009.2.

17. VSRH: Gzz-3/95 - INF 4710/99.

18. VSRH: $\operatorname{Rev} x-77 / 2008-2$ (12.11.2008.) INF 5857 od 24.4.2010.

19. VSRH: Rev-1013/2004-2 od 7.3.206, Rev-2263/1998-2 od 5.12.2001.

20. VSRH: Rev-2080/91 - IO 1993/25; Rev-1090/92 - IO 1994/287.

21. VSRH: Rev-2442/98 17.7.2001. 158, 164/7.

22. VSRH: Rev-2603/2011 - IO VSRH 2/2014-180. (odluka od 19.2.2013.), pozivajući se na svoje odluke broj Revr-1428/209-2 od 27.10.2010. i Rev-402/04-2 od 21.9.2005. 
23. VSRH: Rev-402/04 - INF-N5533/07.

24. VSRH: Rev-744/2010-2 - IO VSRH 1/2011-188., pozivajući se i na svoju odluku broj Rev-100/00-2 od 23.9.2003.

25. VSRH: Revr-1426/2010-2 - IO

26. VSRH: Revt-169/2011-2 - IO VSRH 2/2013-201.

27. VSRH: Revt-245/2011-2 - IO VSRH 2/2011-198.

28. VSRH: Revx-794/2012-2 - IO VSRH 2/2014-182.

29. VSSL II Ips 399/2004 od 27.10.2005.

30. VSV: Gž-133/1960, Glasnik 8/196.

31. ŽS BJ: Gž-1448/00 - IO 1/01-176.

32. ŽS PU: Gž-1683/2009-2 od 8. lipnja 2009.

33. ŽS RI Gž-357/99 - IO-1/00-154.

34. ŽS RI: Gž- 947/98 - ING PSP 2000-8-6.

35. ŽS RI: Gž-2516/00 - IO 1/02-198.

36. ŽS ST: Gžmal-718/2010 - IO VSRH 2/2010-191.

37. ŽS ST: Gžnš-383/2012 - IO VSRH 1/2014.-197. 154/2.

38. ŽS VŽ: GŽ-2428/02 od 12.3.2003.

39. ŽS ZG: Gž-1967/98 - ING PSP 1999-8-56.

40. ŽS ZG: Gž-3422/96.

41. ŽS ZG: Gž-3451/96.

42. ŽS ZG: Gž-3451/96; Gž-3422/96.

43. ŽS ZG: Gž-5763/07 23.10.2007. INF-N 5706/08.

44. ŽS ZG: Gž-6305/01 - ING PSP 2002-8-136.

45. ŽS ZG: gŽ-8126/01 - ING PSP 2003-8-119.

46. ŽS ZG: GŽ-892/2010-2 - IO VSRH 2/2010-190.

47. ŽS ZG: GŽr-437/08 - INF-N 5707/08.

48. ŽS ZG: Gžr-437/08 - INF-N 5707/08. 
Mihajlo Dika*

Summary

\section{REIMBURSEMENT OF COSTS IN CASE OF WITHDRAWAL OF THE CLAIM AND WAIVER OF THE CLAIM UNDER THE 2019 CIVIL PROCEDURE ACT}

Prior to the 2019 Civil Procedure Act Amendments, the plaintiff who withdrew the claim was required to reimburse the litigation costs, unless the claim was withdrawn immediately after the defendant had satisfied the plaintiff's request, in which case the plaintiff was obliged to reimburse the defendant. These provisions were amended in 2019 whereby a plaintiff who withdraws a claim or waives a claim is obliged to reimburse the defendant for the costs of the proceedings, unless the plaintiff has taken such action after the defendant complied with his claim or for other reasons attributable to the defendant, in which case the defendant is obliged to reimburse the costs of the proceedings. The paper, in the framework of the systematic and complete treatment of the institute governed by the aforementioned standards, seeks to determine the meaning and reach of the new amendments. Special focus is on a number of positions taken in jurisprudence and doctrine based on the pre-existing organization of the institute from the aspect of its new normative regulation.

Keywords: compensation of cost; withdrawal of claim; waiver of claim, 2019 amendments of Civil Procedure Act.

Zusammenfassung

\section{KOSTENERSTATTUNG BEI KLAGERÜCKNAHME UND BEI VERZICHT AUF KLAGEANSPRUCH LAUT NOVELLIERTER ZIVILPROZESSORDNUNG}

Vor der Novelle der Zivilprozessordnung in 2019 war der Kläger, der die Klage rückgenommen hat, verpflichtet, der anderen Partei die Verfahrenskosten zu erstatten. Die Ausnahme war, wenn die Klage gleich nach der Befriedigung des Klageanspruchs vonseiten des Beklagten rückgenommen würde, in welchem Fall der Beklagte dem Kläger die Kosten erstatten musste. Durch die Novelle in 2019 sind die genannten Bestimmungen durch neue ersetzt worden, gemäß welchen der Kläger, der die Klage

* Mihajlo Dika, Ph.D., Professor Emeritus, Faculty of Law, University of Zagreb; mihajlo.dika@, pravo.hr. 
rücknimmt oder auf Klageanspruch verzichtet, dem Beklagten die Verfahrenskosten erstatten muss, außer wenn der Kläger diese Handlungen nach der Befriedigung des Klageanspruchs vonseiten des Beklagten unternimmt. In diesem Fall und in anderen Fällen, wo es Gründe gibt, die dem Beklagten zugeschrieben werden können, ist der Beklagte verpflichtet, dem Kläger die Kosten zu erstatten. In diesem Beitrag versucht man im Rahmen der systematischen und erschöpfenden Bearbeitung des durch die genannten Normen regulierten Instituts, die Bedeutung und den Anwendungsbereich der durch die Novelle 2019 eingeführten Neuigkeiten zu bestimmen. Dabei problematisiert man auch die Relevanz des Zahlreichs der in der Rechtsprechung und der Doktrin angenommenen Stellungen vor der Gültigkeit des neuen Instituts aus der Perspektive der neuen normativen Regelung.

Schlüsselwörter: Kostenerstattung; Klagerücknahme; Verzicht auf

Klageanspruch; Novelle der Zivilprozessordnung 2019.

Riassunto

\section{RIMBORSO DELLE SPESE NEL CASO DEL RITIRO DELL'AZIONE E DELLA RINUNCIA ALLA DOMANDA IN SEGUITO ALLA NOVELLA DELLA LEGGE SUL PROCESSO CIVILE}

Novella della Legge sul processo civile del 2019, l'attore che avrebbe ritirato l'azione sarebbe stato obbligato a rimborsare le spese processuali alla parte opposta, tranne il caso in cui l'azione fosse stata ritirata subito dopo l'adempimento dell'obbligo richiesto dal convenuto all'attore, nel quale caso il convenuto sarebbe stato obbligato a rimborsare le spese processuali. Con l'emendamento del 2019 le disposizioni menzionate sono state sostituite con quelle nuove secondo le quali l'attore che ritirerebbe l'azione o che rinuncerebbe alla domanda sarebbe obbligato a rimborsare le spese processuali al convenuto, eccetto se l'attore abbia condotto queste azioni dopo l'adempimento dell'obbligo richiesto dal convenuto oppure per altre ragioni che si possono ascrivere al convenuto, nel quale caso il convenuto sarebbe obbligato a rimborsare le spese processuali all'attore. Nel lavoro, entro il quadro di esaminazione sistematica e completa dell'istituto regolato con le norme menzionate, si tenta di determinare il significato e la portata delle novità introdotte in questo istituto con la novella del 2019. Contemporaneamente si problematizza in particolare la rilevanza degli orientamenti invalsi nella giurisprudenza e nella dottrina in base alla previa disciplina dell'istituto che è stata in vigore e ciò nella prospettiva della sua nuova determinazione normativa.

Parole chiave: rimborso delle spese; ritiro dell 'azione; rinuncia alla domanda; novella della Legge sul processo civile del 2019. 
